\title{
STOCHASTIC DOMINANCE BOUNDS ON DERIVATIVE PRICES IN A MULTIPERIOD ECONOMY WITH PROPORTIONAL TRANSACTION COSTS
}

\author{
George M. Constantinides \\ Stylianos Perrakis \\ Working Paper 8867 \\ http://www.nber.org/papers/w8867 \\ NATIONAL BUREAU OF ECONOMIC RESEARCH \\ 1050 Massachusetts Avenue \\ Cambridge, MA 02138 \\ April 2002
}

\begin{abstract}
We thank Michael Brennan, Phil Dybvig, Steve Heston, Haim Levy, Rajnish Mehra (the editor), Rene Stulz, Robert Tompkins (the referee), and Thaleia Zariphopoulou, for helpful comments. We also thank Ilan Cooper for computational assistance. We remain responsible for errors. Constantinides acknowledges financial support from the Center for Research in Security Prices, University of Chicago. The views expressed herein are those of the authors and not necessarily those of the National Bureau of Economic Research.
\end{abstract}

(C) 2002 by George M. Constantinides and Stylianos Perrakis. All rights reserved. Short sections of text, not to exceed two paragraphs, may be quoted without explicit permission provided that full credit, including (C) notice, is given to the source. 
Stochastic Dominance Bounds on Derivative Prices in a

Multiperiod Economy with Proportional Transaction Costs

George M. Constantinides and Stylianos Perrakis

NBER Working Paper No. 8867

April 2002

JEL No. G13

\section{ABSTRACT}

By applying stochastic dominance arguments, upper bounds on the reservation write price of European calls and puts and lower bounds on the reservation purchase price of these derivatives are derived in the presence of proportional transaction costs incurred in trading the underlying security. The primary contribution is the derivation of bounds when intermediate trading in the underlying security is allowed over the life of the option. A tight upper bound is derived on the reservation write price of a call and a tight lower bound is derived on the reservation purchase price of a put. These results jointly impose tight upper and lower bounds on the implied volatility.

George M. Constantinides

Graduate School of Business

University of Chicago

1101 E. 58th Street

Chicago, IL 60637

and NBER

773-702-7258

gmc@gsb.uchicago.edu
Stylianos Perrakis

The John Molson School of Business

Concordia University

1445 de Maisonneuve W.

Montreal, Quebec

Canada H3G 1M8 


\section{Introduction and Summary}

The paper examines the role of one market imperfection-proportional transaction costs in trading the underlying security—on the observed discrepancy of European option prices from the prices that would prevail in a frictionless market. We derive upper bounds on the reservation write prices of call and put options and lower bounds on the reservation purchase prices of call and put options by extending stochastic dominance arguments to incorporate proportional transaction costs.

The main contribution of this paper is the derivation of stochastic dominance bounds in the case that trading is permitted over the life of the option. These bounds are tight. Furthermore, the upper bound on the reservation write price of a European call option, derived in Proposition 1, and the lower bound on the reservation purchase price of a European put option, derived in Proposition 6, are invariant to the frequency of trading permitted over the life of the option. These results are to be contrasted to the upper bounds on the call option price derived by the super-replication method of Bensaid et. al. (1992) and the approximate replication method of Leland (1985). The latter upper bounds tend to the stock price, as the frequency of trading increases.

An attractive feature of our bounds is that they may be derived for any given arbitrary distribution of the stock price, if the stock price is bounded below by zero and the first moment exists. In particular, as the trading frequency increases, the stock price process need not 
converge to the lognormal, but may converge to a mixed diffusion - point process. Even if we were to set the transaction cost rate equal to zero, it is nowhere assumed that the market is either complete or tends to a complete market, as the frequency of trading increases. Thus, the model accommodates stochastic volatility and stock price jumps. ${ }^{1}$

The results of this paper are related to earlier results on option bounds in incomplete markets, originally derived by Perrakis and Ryan (1984) and extended by Ritchken (1985) and Levy (1985). These bounds were extended to a multiperiod setup by Perrakis (1986, 1988), and Ritchken and Kuo (1988), as a generalization of the binomial option pricing model. ${ }^{2}$

The results of this paper are also related to earlier results by Constantinides and Zariphopoulou $(1999,2001){ }^{3}$ Specifically, Constantinides and Zariphopoulou (2001) assumed that (i) the utility

\footnotetext{
${ }^{1}$ Since the market is incomplete, the bounds need not tend to the Black-Scholes option price, as the frequency of trading increases, even if the transaction costs rate is set equal to zero.

${ }^{2}$ Indeed, these bounds have been shown to coincide with the binomial option price when the return distribution achieves only two values, and to converge to the Black-Scholes (1973) value when the multiperiod returns tend to a diffusion process. See Perrakis (1986) for the binomial model and Perrakis (1988) for the convergence in the trinomial model to the Black-Scholes price.

${ }^{3}$ The basic idea behind both papers is the following. One finds the minimal wealth level of an investor at which it is feasible to write a call option. At that minimal wealth level, the optimal policy over the lifetime of the option is to consume nothing and refrain from trading. This property simplifies the derivation of the reservation write price of a call option at the minimal wealth level. The last but non-trivial step is the demonstration that the reservation write price at the minimal wealth level serves as an upper bound on the reservation write price at all feasible wealth
} 
function exhibits constant relative risk aversion (RRA) that lies between zero and one; (ii) there are multiple risky securities; and (iii) the vector of asset returns is an i.i.d. process in either a discrete-time or a continuous-time framework. Whereas the resulting upper bound on the reservation write price of a European call option is weaker than the upper bound derived in the present paper, the comparative advantage of the Constantinides and Zariphopoulou (2001) approach is that the derivative need not be European and its payoff need not be convex and path independent. Therefore, pricing bounds may be derived for a broader set of derivatives. Constantinides and Zariphopoulou (1999) replaced the assumption that the utility function exhibits constant RRA with the weaker assumption that the utility function is bounded from above and below by two "utility functions" that exhibit constant RRA.

In Section 2, we introduce a single-period economy. There are two primary securities, a riskless bond, and a risky stock, interpreted as a stock market index. There are also cash-settled call options written on the stock that expire at the end of the period. The stock is interpreted as the stock market index. Trading occurs only at the beginning and the end of the period. Trading in the stock incurs proportional transaction costs. The investors maximize expected utility of wealth at the end of the period. In Section 3, we derive stochastic dominance bounds on the reservation purchase price and on the reservation write price of a call option.

In Section 4, we introduce a multiperiod economy. The critical generalization is that trading is permitted over the life of the option. Another non-critical generalization is that an investor's

levels. 
horizon may extend beyond the expiration date of the option. A limiting assumption in this economy is that the rate of return on the stock is independently (but not necessarily identically) distributed.

In Section 5, we derive stochastic dominance bounds on the reservation purchase price and on the reservation write price of a call option, in the multiperiod economy. The upper bound derived in Proposition 1 is invariant to the frequency of trading permitted over the life of the option. The upper bound derived in Proposition 2, and the lower bounds derived in Propositions 3 - 5 depend on the modeled frequency of trading over the life of the option.

In Section 6, we generalize the results in two directions. In Section 6.1, we sketch the derivation on bounds on the reservation prices of put options. In particular, in Proposition 6, we provide a lower bound on the reservation purchase price of a put option. It has the distinguishing feature, along with Proposition 1, that it is independent of the trading frequency. In Section 6.2, we sketch the derivation of bounds on options with physical delivery. In Section 7, we specialize the stock price probability distribution to be lognormal. We show that the upper bound on the reservation write price of a call option is tight both in absolute terms and in comparison to Leland's (1985) bounds. We also show that the lower bound on the reservation purchase price of a put option is tight. These results jointly impose tight upper and lower bounds on the implied volatility.

In the remainder of this section, we complete the literature review. Merton (1990), and Boyle 
and Vorst (1992) considered a self-financing policy that replicates the payoff of a long call option in the presence of proportional transaction costs, when the stock price process is binomial. The cost of the dominating policy tends to the stock price as the density of the binomial steps tends to infinity. Bensaid et. al. (1992) introduced the notion of super-replication, which replaces the goal of replicating the payoff of a call option with the goal of dominating it. They showed that super-replication coincides with replication for physical delivery options, as well as for all types of options, when the transaction cost rate is low. Hence, in this case as well, the cost of the dominating policy tends to the stock price as the density of the binomial steps tends to infinity. See also Edirisinghe, Naik and Uppal (1993). Perrakis and Lefoll (1997) showed that a similar trivial bound holds for the portfolio replicating the short call option. In a fairly general setting, Davis and Clark (1993) conjectured and Soner, Shreve and Cvitanic (1995) proved that the stock price is indeed the minimum-cost dominating policy for the long call option in the presence of proportional transaction costs, however small the (finite) proportional transaction cost rate may be.

Leland (1985) introduced a class of imperfectly replicating policies in the presence of proportional transaction costs. He calculated the total cost, including transaction costs, of an imperfectly replicating policy and the "tracking error", that is, the standard deviation of the difference between the payoff of the option and the payoff of the imperfectly replicating policy. Related work includes Avellaneda and Paras (1994), Brennan and Schwartz (1979), Figlewski (1989), Grannan and Swindle (1996), Hoggard, Whalley and Wilmott (1993), and Toft (1996). 
Hodges and Neuberger (1989), and Davis, Panas and Zariphopoulou (1993) computed explicitly an investor's reservation purchase and write prices of a call option. They solved numerically for the optimal multi-period investment policy in the bond, stock and option, under the assumption that the utility function is exponential, with given absolute risk aversion coefficient.

\section{The Single-Period Economy}

We present the main results first in the context of a single-period economy. There are three types of financial assets: a default-free bond, a non-dividend-paying stock, and a cash-settled call option on the stock. Since the stock is the only primary risky asset, it has the natural interpretation as the stock market portfolio or index. The option has the natural interpretation as an index option. The assets may be traded only at the initial date (the beginning of the period) and the terminal date (the end of the period). An investor may hold long or short positions in these assets. The terminal date is chosen to coincide with the expiration date of the option. Obviously, this is a limitation of the single-period economy and is eliminated in the multiperiod economy.

A bond with price one at the initial date has price $\mathrm{R}, \mathrm{R}>1$, at the terminal date, where $\mathrm{R}$ is a constant. The bond trades do not incur transaction costs. The stock price is $\mathrm{S}_{0}$ at the initial date and $\mathrm{S}$ at the terminal date. We assume that $\mathrm{S}_{0}>0$ and that the support of $\mathrm{S}$ is the interval $[0, \infty){ }^{4}$

\footnotetext{
${ }^{4}$ The case where the support of $S$ is the interval $\left[S^{\prime}, S^{\prime \prime}\right]$, where $S^{\prime}>0$, and $S^{\prime \prime} \leq \infty$ results in a significant tightening of the bounds. This case will be discussed also.
} 
At the initial and terminal dates, the stock trades incur proportional transaction costs, charged to the bond account. The investor pays $\left(1+\mathrm{k}_{1}\right) \mathrm{S}_{0}$ out of the bond account to purchase one share of stock at the initial date. The investor is credited $\left(1-\mathrm{k}_{2}\right) \mathrm{S}_{0}$ in the bond account to sell (or, sell short) one share of stock at the initial date. We assume that $0 \leq \mathrm{k}_{1}<1$ and $0 \leq \mathrm{k}_{2}<1$. The same proportional transaction cost structure applies at the terminal date.

We make the plausible assumption that the expected return on the stock, gross of transaction costs, exceeds the bond return:

$$
\mathrm{E}\left[\mathrm{S} / \mathrm{S}_{\mathrm{o}}\right]>\mathrm{R} \text {. }
$$

We define the expected return on the stock, net of transaction costs, $\mathrm{R}^{*}$, as

$$
\mathrm{R}^{*} \equiv\left\{\left(1-\mathrm{k}_{2}\right) /\left(1+\mathrm{k}_{1}\right)\right\} \mathrm{E}\left[\mathrm{S} / \mathrm{S}_{\mathrm{o}}\right]
$$

We derive bounds on the option price in both cases, $\mathrm{R}^{*}>\mathrm{R}$ and $\mathrm{R}^{*} \leq \mathrm{R}$. Both cases are plausible, depending on the length of the time period and the levels of transaction costs $\mathrm{k}_{1}$ and $\mathrm{k}_{2}$.

Each investor is endowed with certain quantities of the bond, the stock, and European-style derivatives on the stock that expire at the terminal date. The investors trade at the initial date, incurring in the process transaction costs. At the terminal date, they sell (or, close the short positions in) the bond and stock accounts, and exercise (or be exercised upon) their options, if it 
is optimal to do so. ${ }^{5}$

Let $\mathrm{W}=\mathrm{W}(\mathrm{S})$ denote an investor's wealth at the terminal date, net of transaction costs, as a function of the stock price, $\mathrm{S}$, at the terminal date. If the investor's utility is defined only for non-negative terminal wealth, then a portfolio is feasible, if $\mathrm{W} \geq 0$ with probability one. In that case we confine our attention to cases where the initial endowment is such that the set of feasible policies is non-empty. If the investor's utility is defined for both positive and negative terminal wealth, as, for example, in the case of exponential utility, then the set of feasible policies is nonempty for any initial endowment. In the next section, we consider the case that utility is defined only for non-negative terminal wealth and sketch the other case in footnotes.

The investor's expected utility is $\mathrm{E}[\mathrm{u}(\mathrm{W}(\mathrm{S}))]$, where $\mathrm{E}[\cdot]$ denotes the expectation, conditional on $\mathrm{S}_{\mathrm{o}}$. We make the plausible assumption that the utility function, $\mathrm{u}(\cdot)$, is increasing and concave. At the initial date, the investor chooses a feasible policy to maximize expected utility.

\footnotetext{
${ }^{5}$ In the single-period economy, we cannot distinguish between the expiration date of the option and the end of the investor's horizon. Hence the unsatisfactory assumption that the investor liquidates the stock account on the expiration date of the option. One implication of this assumption is that the transaction costs of liquidating the stock account are sunk costs. In section 4, we model a multiperiod economy. The investor's horizon may be longer than the term of the option's maturity and may even be infinite. Then the investor need not liquidate the stock account on the expiration date of the option.
} 


\section{Option Bounds in the Single-Period Economy}

We derive option bounds in a single-period economy. Specifically, we derive two upper bounds on the reservation write price and two lower bounds on the reservation purchase price of a European, cash-settled call option on the stock with payoff $[\mathrm{S}-\mathrm{K}]^{+}$at the terminal date. The major simplifying feature of a single-period economy is that trading is allowed only at two dates, the beginning and the end of the period. The complication of intermediate trading is introduced in the next section, in the context of a multiperiod economy.

We focus on the case that the investor's utility is defined only for non-negative terminal wealth. The bounds derived below remain valid when utility is defined for both positive and negative terminal wealth. The minor modifications in the argument are sketched in footnotes.

We derive the bounds by considering an investor with optimal policy such that the investor's wealth at the terminal date, $\mathrm{W}(\mathrm{S})$, satisfies the following two properties: (1) $\mathrm{W}(0)=\mathrm{I} \geq 0{ }^{6}$; and (2) $\mathrm{W}(\mathrm{S})$ - NS is non-decreasing in $\mathrm{S}$, for $\mathrm{S} \geq 0$, where $\mathrm{N}>0$. In general, the investor's portfolio includes derivatives on the stock, and $\mathrm{W}(\mathrm{S})$ is not an affine function of $\mathrm{S} .^{7}$

\footnotetext{
${ }^{6}$ If utility is defined for both positive and negative terminal wealth, then the condition $\mathrm{I} \geq 0$ is eliminated.

${ }^{7}$ We motivate the properties (1) and (2) in the special case that the investor's portfolio consists of investment in the bond and stock (the market portfolio) but not in derivatives. We denote by $\mathrm{I} / \mathrm{R}$ the dollar investment in the bond and by $\mathrm{N} /\left(1-\mathrm{k}_{2}\right)$ the number of shares of stock held. Then the wealth at the terminal date is $\mathrm{W}(\mathrm{S})=\mathrm{I}+\mathrm{NS}$. Necessary conditions that guarantee the non-negativity of net worth are $\mathrm{I} \geq 0$ and $\mathrm{N} \geq 0$. The condition $\mathrm{I} \geq 0$ implies the
} 
Let $\mathrm{C}$ be the price at which the investor can write the call option. To derive the first upper bound on the reservation write price, we consider the zero-net-cost position which consists of: (a) a short position in $\mathrm{n}$ calls, where $0<\mathrm{n} \leq \mathrm{N}$; and (b) a long position in $\mathrm{nC} /\left(1+\mathrm{k}_{1}\right) \mathrm{S}_{0}$ shares of stock. At the terminal date the payoff is $\mathrm{h}(\mathrm{S})$, where

$$
\mathrm{h}(\mathrm{S})=\left\{\left(1-\mathrm{k}_{2}\right) /\left(1+\mathrm{k}_{1}\right)\right\} \mathrm{nCS} / \mathrm{S}_{0}-\mathrm{n}[\mathrm{S}-\mathrm{K}]^{+} .
$$

The policy is feasible because $\mathrm{W}(\mathrm{S})+\mathrm{h}(\mathrm{S}) \geq 0{ }^{8}$. This follows from the fact that, by assumption, $\mathrm{W}(\mathrm{S}) \geq 0$ and $\mathrm{n} \leq \mathrm{N}$. Note that $\mathrm{h}(\mathrm{S}) \underset{<}{>}$ as $\mathrm{S}>\hat{S}$, where the stock price $\hat{S}$ is defined by $\mathrm{h}(\hat{S})=0$ and $\hat{S}>0$. Note also that $\mathrm{W}(\mathrm{S})+\mathrm{h}(\mathrm{S})$ is increasing in $\mathrm{S}$ everywhere, even though $\mathrm{h}(\mathrm{S})$ is not. The increase in expected utility in writing the $\mathrm{n}$ calls is

$$
\begin{array}{r}
E[\mathrm{u}(\mathrm{W}(\mathrm{S})+\mathrm{h}(\mathrm{S}))]-\mathrm{E}[\mathrm{u}(\mathrm{W}(\mathrm{S}))] \\
\quad \geq \mathrm{E}\left[\mathrm{u}^{\prime}(\mathrm{W}(\mathrm{S})+\mathrm{h}(\mathrm{S})) \mathrm{h}(\mathrm{S})\right]
\end{array}
$$

(by the concavity of $u(\cdot)$ )

assumed property (1). We motivate the assumed property $\mathrm{N}>0$ by the observation that at least some investors hold the market that is in positive net supply.

${ }^{8}$ If utility is defined for both positive and negative terminal wealth, then the policy is feasible irrespective of whether the condition $\mathrm{W}(\mathrm{S})+\mathrm{h}(\mathrm{S}) \geq 0$ holds or not. 


$$
\geq \mathrm{E}\left[\mathrm{u}^{\prime}(\mathrm{W}(\hat{S})+\mathrm{h}(\hat{S})) \mathrm{h}(\mathrm{S})\right]
$$

(since $\mathrm{u}^{\prime}(\mathrm{W}(\mathrm{S})+\mathrm{h}(\mathrm{S}))$ is decreasing in $\mathrm{S}$ and $\mathrm{h}(\mathrm{S}) \stackrel{>}{<}$ as $\mathrm{S}>\hat{S}$ )

$$
\geq \mathrm{u}^{\prime}(\mathrm{W}(\hat{S})+\mathrm{h}(\hat{S})) \mathrm{E}[\mathrm{h}(\mathrm{S})]
$$

$>0$, unless

$$
\mathrm{E}[\mathrm{h}(\mathrm{S})] \leq 0
$$

This simplifies into

$$
\mathrm{C} \leq \mathrm{E}\left[[\mathrm{S}-\mathrm{K}]^{+}\right] / \mathrm{R}^{*} \equiv \bar{C}_{1}
$$

If equation (3.4) is violated, the investor increases expected utility by writing $\mathrm{n}$ calls. Therefore, $\bar{C}_{1}$ is an upper bound on the reservation write price of as many as $N$ call options. ${ }^{9}$

\footnotetext{
${ }^{9}$ If $\mathrm{S}$ is bounded from below by a strictly positive number $\mathrm{S}^{\prime}$, and if $\mathrm{R}^{*}>\mathrm{R}$, then the upper bound in (3.4) may be tightened as

$$
\bar{C}_{1^{\prime}}=\left\{\left(\mathrm{R}-\mathrm{R}_{1}\right) \mathrm{E}\left[[\mathrm{S}-\mathrm{K}]^{+}\right]+\left(\mathrm{R}^{*}-\mathrm{R}\right)\left[\mathrm{S}^{\prime}-\mathrm{K}\right]^{+}\right\} / \mathrm{R}\left(\mathrm{R}^{*}-\mathrm{R}_{1}\right), \text { if } \mathrm{S} \geq \mathrm{S}^{\prime}>0 \text {, and } \mathrm{R}^{*}>\mathrm{R}
$$

where $\mathrm{R}_{1} \equiv \mathrm{S}^{\prime}\left(1-\mathrm{k}_{2}\right) / \mathrm{S}_{0}\left(1+\mathrm{k}_{1}\right)$ and $\mathrm{R}^{*}$ is defined in equation (2.2). The proof is an adaptation of the proof in Perrakis (1986) to allow for proportional transaction costs. The difference now is that the zero-net-cost position, while it still
} 
Investors with different utility functions have a different reservation write price of a call option. Some investors may have a reservation write price below $\bar{C}_{1}$. However, no risk averse (or, riskneutral) investor with $\mathrm{N}>0$ has a reservation write price above $\bar{C}_{1}$.

We obtain a second upper bound on the reservation write price of a call by considering the following zero-net-cost position: (a) write $\mathrm{n}$ call options, where $0<\mathrm{n} \leq \mathrm{N}$; and (b) invest $\mathrm{nC}$ in the bond. At the terminal date the payoff, $\mathrm{h}(\mathrm{S})$, is

$$
h(S)=-n[S-K]^{+}+n R C
$$

The policy is feasible because $\mathrm{W}(\mathrm{S})+\mathrm{h}(\mathrm{S}) \geq 0 .{ }^{10}$ The stock price $\hat{S}$ is defined implicitly by $\mathrm{h}(\hat{S})=0$. Note that $\mathrm{h}(\mathrm{S})>0$ as $\mathrm{S}>\hat{S}$. Note also that $\mathrm{W}(\mathrm{S})+\mathrm{h}(\mathrm{S})$ is increasing in $\mathrm{S}$.

contains a long position of $\mathrm{nC} /\left(1+\mathrm{k}_{1}\right) \mathrm{S}_{0}$ shares of stock, is short in the riskless asset, as well as in the calls. The portion $\alpha \mathrm{nC}$ of borrowed money is set by the requirement that the net wealth at $\mathrm{S}=\mathrm{S}^{\prime}$ must be equal to zero, so that it stay initially nonnegative. We have two cases: either $\mathrm{S}^{\prime}<\mathrm{K}$, in which case it can be shown that $\alpha=\mathrm{R}_{1} / \mathrm{R}$; or $\mathrm{S}^{\prime} \geq$ $\mathrm{K}$, resulting in $\alpha=\mathrm{K}\left(1-\mathrm{k}_{2}\right) / \mathrm{RS}_{0}\left(1+\mathrm{k}_{1}\right)$. The first case yields a call option upper bound equal to $\left(\mathrm{R}-\mathrm{R}_{1}\right) \mathrm{E}\left[\left[\mathrm{S}-\mathrm{K}^{+}\right]\right]$/ $\left(\mathrm{R}^{*}-\mathrm{R}_{1}\right) \mathrm{R}$, while the second one ends up with the well-known value of the option when it is always in the money, $\mathrm{S}_{0}\left(1+\mathrm{k}_{1}\right) /\left(1-\mathrm{k}_{2}\right)-\mathrm{K} / \mathrm{R}$. We combine the two values and obtain equation (3.4)'.

${ }^{10}$ If utility is defined for both positive and negative terminal wealth, then the policy is feasible irrespective of whether the condition $\mathrm{W}(\mathrm{S})+\mathrm{h}(\mathrm{S}) \geq 0$ holds or not. 
Proceeding as before, we find that the investor increases expected utility by writing a call option, unless $\mathrm{E}[\mathrm{h}(\mathrm{S})] \leq 0$, which simplifies into

$$
\mathrm{C} \leq \mathrm{E}\left[[\mathrm{S}-\mathrm{K}]^{+}\right] / \mathrm{R} \equiv \bar{C}_{2} .
$$

Note that $\bar{C}_{1}>\bar{C}_{2}$ as R ${ }^{*}>\mathrm{R}$. We combine the results of equations (3.4) and (3.6) and conclude that $\min \left[\bar{C}_{1}, \bar{C}_{2}\right]$ is an upper bound on the reservation write price of as many as $N$ call options. In the absence of transaction costs, the bound becomes identical to the upper bound originally derived by Perrakis and Ryan (1984), and re-derived by different methods by Levy (1985) and Ritchken (1985).

We derive next two lower bounds on the reservation purchase price of a call option. Let $\mathrm{C}$ be the price at which the investor can purchase the call option. First, we prove the following preliminary result. If at least one investor holds $\mathrm{N} /\left(1-\mathrm{k}_{2}\right)$ shares of stock, where $\mathrm{N}>0$, then absence of arbitrage requires that $\mathrm{C}$ satisfy the restrictions ${ }^{11}$

$$
\left[\mathrm{S}_{0}-\mathrm{K} / \mathrm{R}, 0\right]^{+} \leq \mathrm{C} \leq \mathrm{S}_{0}\left(1+\mathrm{k}_{1}\right) /\left(1-\mathrm{k}_{2}\right) .
$$

\footnotetext{
${ }^{11}$ Consider first the left-hand inequality. If $\mathrm{S}_{0}-\mathrm{K} / \mathrm{R} \leq 0$, violation of equation (3.7) implies arbitrage. If $\mathrm{S}_{0}-\mathrm{K} / \mathrm{R}$ $>0$, and equation (3.7) is violated, an investor earns arbitrage profit $\left\{\mathrm{C}-\mathrm{S}_{0}-\mathrm{K} / \mathrm{R}\right\} \mathrm{n}$ by buying $\mathrm{n} /\left(1-\mathrm{k}_{2}\right)$ call options, where $0<\mathrm{n} \leq \mathrm{N}$, selling $\mathrm{n}$ shares of stock, and investing $\mathrm{nK} / \mathrm{R}$ in bonds. At the end of the period, the wealth is $\mathrm{I}+(\mathrm{N}-\mathrm{n}) \mathrm{S}+\mathrm{n}[\mathrm{S}-\mathrm{K}]^{+}+\mathrm{nK} \geq \mathrm{I}+\mathrm{NS}$. Similar arguments establish the right-hand inequality.
} 
Let $g$ be a parameter that satisfies the restriction

$$
\mathrm{C}\left(1-\mathrm{k}_{2}\right) / \mathrm{S}_{0}\left(1+\mathrm{k}_{1}\right) \leq \mathrm{g} \leq 1 .
$$

Consider the zero-net-cost position consisting of: (a) the purchase of $n$ call options, where $0<n$ $\leq \mathrm{N}$; (b) the sale of $n g /\left(1-\mathrm{k}_{2}\right)$ shares of stock out of the inventory of $\mathrm{N} /\left(1-\mathrm{k}_{2}\right)$ shares; and (c) the investment of $\mathrm{n}\left(\mathrm{gS}_{0}-\mathrm{C}\right)$ in bonds. At the terminal date the payoff is $\mathrm{h}(\mathrm{S})$, where ${ }^{12}$

$$
\mathrm{h}(\mathrm{S})=\mathrm{n}[\mathrm{S}-\mathrm{K}]^{+}-\mathrm{ngS}+\mathrm{nR}\left(\mathrm{gS}_{0}-\mathrm{C}\right)
$$

The reader may verify the following properties: $h(0) \geq 0 ; h(S)$ is decreasing and affine in $S$, for $\mathrm{S}<\mathrm{K} ;$ and $\mathrm{h}(\mathrm{K})<0$. Therefore, the equation $\mathrm{h}(\mathrm{S})=0$ has one and only one root in the interval $[0, \mathrm{~K}]$, given by

$$
\mathrm{S}_{1}=\mathrm{R}\left(\mathrm{S}_{0}-\mathrm{C} / \mathrm{g}\right) .
$$

\footnotetext{
${ }^{12}$ At the end of the period, the wealth is $\mathrm{I}+(\mathrm{N}-\mathrm{n}) \mathrm{S}+\mathrm{gnS}_{0}[\mathrm{~S}-\mathrm{K}]^{+} / \mathrm{C}+(1-\mathrm{g}) \mathrm{nS}_{0} \mathrm{R}$ and exceeds the wealth $\mathrm{I}+\mathrm{NS}$ by $\mathrm{h}(\mathrm{S})$, as given in equation (3.9). The payoff is independent of the transaction cost rates, $\mathrm{k}_{1}$ and $\mathrm{k}_{2}$. An implication of this is that both of the lower bounds derived here (equations (3.15) and (3.16)) are independent of the transaction cost parameters. This is a feature specific to the single-period economy and does not carry over to the multiperiod economy.
} 
If $\mathrm{g}<1$, then $\mathrm{h}(\mathrm{S})$ is increasing and affine in $\mathrm{S}$ for $\mathrm{S}>\mathrm{K}$. Then the equation $\mathrm{h}(\mathrm{S})=0$ has a second root, $\mathrm{S}_{2}$. This root lies in the interval $[\mathrm{K}, \infty)$ and is given by ${ }^{13}$

$$
\mathrm{S}_{2}=\left\{\mathrm{K}-\mathrm{R}\left(\mathrm{gS}_{0}-\mathrm{C}\right)\right\} /(1-\mathrm{g})
$$

Note that $h(S) \geq 0$, for $0 \leq S \leq S_{1}$ and $S_{2} \leq S$; and $h(S) \leq 0$ for $S_{1} \leq S \leq S_{2}$. The increase in expected utility in purchasing the calls is

$$
\begin{array}{r}
E[\mathrm{u}(\mathrm{W}(\mathrm{S})+\mathrm{h}(\mathrm{S}))]-\mathrm{E}[\mathrm{u}(\mathrm{W}(\mathrm{S}))] \\
\quad \geq \mathrm{E}\left[\mathrm{u}^{\prime}(\mathrm{W}(\mathrm{S})+\mathrm{h}(\mathrm{S})) \mathrm{h}(\mathrm{S})\right]
\end{array}
$$

(by the concavity of $\mathrm{u}(\cdot)$ )

$$
\geq \operatorname{prob}\left(\mathrm{S} \leq \mathrm{S}_{2}\right) \mathrm{E}\left[\mathrm{u}^{\prime}(\mathrm{W}(\mathrm{S})+\mathrm{h}(\mathrm{S})) \mathrm{h}(\mathrm{S}) \mid \mathrm{S} \leq \mathrm{S}_{2}\right]
$$

(since $\mathrm{u}^{\prime}() \geq 0$ and $\mathrm{h}(\mathrm{S}) \geq 0$, for $\mathrm{S}_{2} \leq \mathrm{S}$ )

$$
\geq \operatorname{prob}\left(\mathrm{S} \leq \mathrm{S}_{2}\right) \mathrm{E}\left[\mathrm{u}^{\prime}\left(\mathrm{W}\left(\mathrm{S}_{1}\right)+\mathrm{h}\left(\mathrm{S}_{1}\right)\right) \mathrm{h}(\mathrm{S}) \mid \mathrm{S} \leq \mathrm{S}_{2}\right]
$$

(since $\mathrm{u}^{\prime}\left(\mathrm{W}(\mathrm{S})+\mathrm{h}(\mathrm{S})\right.$ ) is decreasing in $\mathrm{S}, \mathrm{h}(\mathrm{S}) \geq 0$, for $0 \leq \mathrm{S} \leq \mathrm{S}_{1}$, and $\mathrm{h}(\mathrm{S}) \leq 0$ for $\mathrm{S}_{1} \leq \mathrm{S} \leq \mathrm{S}_{2}$ )

\footnotetext{
${ }^{13}$ If $g=1$, then the equation $\mathrm{h}(\mathrm{S})=0$ does not have a second root. With slight abuse of notation, we say that the equation $\mathrm{h}(\mathrm{S})=0$ has a second root at $\mathrm{S}_{2}=\infty$.
} 


$$
\begin{aligned}
& \geq \operatorname{prob}\left(\mathrm{S} \leq \mathrm{S}_{2}\right) \mathrm{u}^{\prime}\left(\mathrm{W}\left(\mathrm{S}_{1}\right)+\mathrm{h}\left(\mathrm{S}_{1}\right)\right) \mathrm{E}\left[\mathrm{h}(\mathrm{S}) \mid \mathrm{S} \leq \mathrm{S}_{2}\right] \\
& >0
\end{aligned}
$$

unless

$$
\mathrm{E}\left[\mathrm{h}(\mathrm{S}) \mid \mathrm{S} \leq \mathrm{S}_{2}\right] \leq 0,
$$

assuming that $\operatorname{prob}\left(\mathrm{S} \leq \mathrm{S}_{2}\right)>0$. This simplifies into

$$
\mathrm{C} \geq \mathrm{E}\left[[\mathrm{S}-\mathrm{K}]^{+} \mid \mathrm{S} \leq \mathrm{S}_{2}\right] / \mathrm{R}-\mathrm{g}\left\{\mathrm{E}\left[\mathrm{S} \mid \mathrm{S} \leq \mathrm{S}_{2}\right]\right\} / \mathrm{R}+\mathrm{gS}_{0} \equiv \underline{\mathrm{C}}\left(\mathrm{g}, \mathrm{S}_{2}\right) .
$$

First, we set $g=1$. Then equation (3.11) states that $\mathrm{S}_{2}=\infty$ and equation (3.15) becomes

$$
\mathrm{C} \geq \mathrm{R}^{-1} \mathrm{E}\left[[\mathrm{S}-\mathrm{K}]^{+}\right]+\mathrm{S}_{0}-\mathrm{R}^{-1} \mathrm{E}[\mathrm{S}] \equiv \underline{\mathrm{C}}_{1} .
$$

We conclude that $\underline{\mathrm{C}}_{1}$ is a lower bound on the reservation purchase price of as many as $N$ call options. This is identical to the lower bound found in Perrakis and Ryan (1984).

If the distribution of $\mathrm{S}$ has a finite support, with $\mathrm{S} \leq \mathrm{S}^{\prime \prime}<\infty$, then the lower bound in (3.15) can be tightened further, by choosing a value of $g<1$ such that $\mathrm{S}_{2}=\mathrm{S}^{\prime \prime}$. The appropriate expression has been derived in Perrakis (1986) and will not be repeated here. In all cases, however, the tightest lower bound, $\underline{\mathrm{C}}_{2}$, is obtained by maximizing $\underline{\mathrm{C}}\left(\mathrm{g}, \mathrm{S}_{2}\right)$ with respect to $\mathrm{g}$ and $\mathrm{S}_{2}$, subject to 
equation (3.10). ${ }^{14}$ This tightest lower bound is ${ }^{15}$

$$
\left.\underline{\mathrm{C}}_{2}=\mathrm{R}^{-1} \mathrm{E}[\mathrm{S}-\mathrm{K}]^{+} \mid \mathrm{S} \leq \mathrm{S}_{3}\right]
$$

where $\mathrm{S}_{3}$ is defined implicitly by

$$
\mathrm{E}\left[\mathrm{S} / \mathrm{S}_{0} \mid \mathrm{S} \leq \mathrm{S}_{3}\right]-\mathrm{R}=0
$$

We conclude that $\underline{\mathrm{C}}_{2}$ is a lower bound on the reservation purchase price of as many as $N$ call options. This bound is identical to the tightest lower bound derived earlier with stochastic dominance arguments by Levy (1985) and Ritchken (1985). The reader may verify that

$$
\underline{\mathrm{C}}_{1} \leq \underline{\mathrm{C}}_{2} \leq \min \left[\bar{C}_{1}, \bar{C}_{2}\right]
$$

and that $\underline{\mathrm{C}}_{1}, \underline{\mathrm{C}}_{2}$, and $\bar{C}_{1}$ are increasing and convex functions of the price $\mathrm{S}_{0}$, with slopes that tend to 1 and $\left(1+\mathrm{k}_{1}\right) /\left(1-\mathrm{k}_{2}\right)$, respectively, as $\mathrm{S}_{0} \rightarrow \infty$.

In the next two sections, we reexamine the bounds when intermediate trading is permitted.

\footnotetext{
${ }^{14}$ The maximizing value of $\mathrm{g}$ is a function of $\mathrm{S}_{0}$. In a multiperiod economy, $\mathrm{g}$ becomes a function of a random variable and this complicates the derivation and numerical calculation of the tightest lower bound.
} 


\section{The Multiperiod Economy}

We generalize the single-period economy to a multiperiod economy. Each investor makes sequential investment decisions at the discrete trading dates $t=0,1, \ldots, \mathrm{T}^{\prime}$, where $\mathrm{T}^{\prime}$ is the terminal date and is finite. ${ }^{16}$ Before the option is introduced, there are two types of financial assets: a default-free bond, and a non-dividend-paying stock. An investor may hold long or short positions in these assets. The bond is default free, pays no coupons and has constant one-plusrate-of-return $\mathrm{R}$ per period, where $\mathrm{R}>0 .{ }^{17}$ The stock pays no dividends. Its price at date $\mathrm{t}$ is denoted by $S_{t}$. We assume that the support of $S_{t}$ is the interval $(0, \infty)$ and that the rates of return on the stock, $\mathrm{S}_{\mathrm{t}} / \mathrm{S}_{\mathrm{t}-1}, \mathrm{~S}_{\mathrm{t}+1} / \mathrm{S}_{\mathrm{t}}, \ldots$, are i.i.d., with $\mathrm{R}_{\mathrm{S}} \equiv \mathrm{E}\left[\mathrm{S}_{\mathrm{t}+1} / \mathrm{S}_{\mathrm{t}}\right] .^{18}$

We consider an investor who enters at date $t$ with dollar holdings $x_{t}$ in the bond account and $y_{t} / S_{t}$ shares of stock. The investor increases (or, decreases) the dollar holdings in the stock account from $\mathrm{y}_{\mathrm{t}}$ to $\mathrm{y}_{\mathrm{t}}+\mathrm{v}_{\mathrm{t}}$ by decreasing (or, increasing) the bond account from $\mathrm{x}_{\mathrm{t}}$ to $\mathrm{x}_{\mathrm{t}}-\mathrm{v}_{\mathrm{t}}-\max \left[\mathrm{k}_{1} \mathrm{v}_{\mathrm{t}}\right.$, $\mathrm{k}_{2} \mathrm{~V}_{\mathrm{t}}$ ], where $0 \leq \mathrm{k}_{1}<1$ and $0 \leq \mathrm{k}_{2}<1$. The decision variable $\mathrm{v}_{\mathrm{t}}$ is constrained to be measurable with respect to the information up to date $t$.

\footnotetext{
${ }^{15}$ The derivation is available from the authors upon request.

${ }^{16}$ The assumption that the time interval between trading dates is one is innocuous: the unit of time is chosen to be such that the time interval between trading dates is one.

${ }^{17}$ The results extend routinely to the case that the rate of interest is time-varying but deterministic.

${ }^{18}$ The results extend routinely to the case that the rates of return on the stock are independently but not identically distributed.
} 
Given the investment decision $\mathrm{v}_{\mathrm{t}}$ at date $\mathrm{t}$, the bond account dynamics is

$$
\mathrm{x}_{\mathrm{t}+1}=\left\{\mathrm{x}_{\mathrm{t}}-\mathrm{v}_{\mathrm{t}}-\max \left[\mathrm{k}_{1} \mathrm{v}_{\mathrm{t}},-\mathrm{k}_{2} \mathrm{v}_{\mathrm{t}}\right]\right\} \mathrm{R}, \quad \mathrm{t} \leq \mathrm{T}^{\prime}-1
$$

and the stock account dynamics is

$$
\mathrm{y}_{\mathrm{t}+1}=\left(\mathrm{y}_{\mathrm{t}}+\mathrm{v}_{\mathrm{t}}\right) \mathrm{S}_{\mathrm{t}+1} / \mathrm{S}_{\mathrm{t}}, \quad \mathrm{t} \leq \mathrm{T}^{\prime}-1
$$

At the terminal date, the stock account is liquidated, $\mathrm{v}_{\mathrm{T}^{\prime}}=-\mathrm{y}_{\mathrm{T}^{\prime}}$. The net worth is defined as

$$
\mathrm{W}_{\mathrm{T}^{\prime}}=\mathrm{x}_{\mathrm{T}^{\prime}}+\mathrm{y}_{\mathrm{T}^{\prime}}-\max \left[-\mathrm{k}_{1} \mathrm{y}_{\mathrm{T}^{\prime}}, \mathrm{k}_{2} \mathrm{y}_{\mathrm{T}^{\prime}}\right]
$$

At each date, the investor chooses the investment $v_{t}$ with the objective to maximize the expected utility of the net worth, $\mathrm{E}\left[\mathrm{u}\left(\mathrm{W}_{\mathrm{T}^{\prime}}\right)\right] .{ }^{19}$. We make the plausible assumption that the utility function, $\mathrm{u}(\cdot)$, is increasing and concave, and is defined for both positive and negative terminal net worth. ${ }^{20}$

${ }^{19}$ The results extend routinely to the case that consumption occurs at each trading date and utility is defined over consumption at each of the trading dates and over the net worth at the terminal date. See, Constantinides (1979) for details. The model with utility defined over terminal net worth alone is a more realistic representation of the objective function of a financial institution.

${ }^{20}$ If utility is defined only for non-negative net worth, then the decision variable is constrained to be a member of a 
We define the value function recursively for $\mathrm{t} \leq \mathrm{T}^{\prime}-1$ as

$$
\mathrm{V}(\mathrm{x}, \mathrm{y}, \mathrm{t}) \equiv \max _{\mathrm{v}} \mathrm{E}\left[\mathrm{V}\left(\left\{\mathrm{x}-\mathrm{v}-\max \left[\mathrm{k}_{1} \mathrm{~V},-\mathrm{k}_{2} \mathrm{~V}\right]\right\} \mathrm{R},(\mathrm{y}+\mathrm{v}) \mathrm{S}_{\mathrm{t}+1} / \mathrm{S}_{\mathrm{t}}, \mathrm{t}+1\right)\right]
$$

and

$$
\mathrm{V}\left(\mathrm{x}, \mathrm{y}, \mathrm{T}^{\prime}\right)=\mathrm{u}\left(\mathrm{x}+\mathrm{y}-\max \left[-\mathrm{k}_{1} \mathrm{y},-\mathrm{k}_{2} \mathrm{y}\right]\right)
$$

We denote by $v_{t}$ the optimal investment decision at date $t$. We assume that the parameters of the problem satisfy appropriate technical conditions such that the value function exists and is once differentiable. The monotonicity and concavity of the utility function, combined with the linearity of the transaction costs structure, imply that the value function, $V(x, y, t)$, is increasing and concave in $(\mathrm{x}, \mathrm{y}) .^{21}$

Next, we enrich the investment opportunity set by introducing a European-style, cash-settled derivative that expires at date $\mathrm{T}, \mathrm{T} \leq \mathrm{T}^{\prime}$. We define by $\mathrm{c}\left(\mathrm{S}_{\mathrm{T}}\right)$ the cash payoff at expiration to an investor that takes a position in this derivative. For example, if an investor buys (writes) $\mathrm{n}$ call

convex set, A, that ensures the non-negativity of the net worth. See, Constantinides (1979) for details. However, the derivation of bounds on the prices of derivatives requires an entirely different approach and yields weaker bounds. This case is studied in Constantinides and Zariphopoulou (1999, 2001).

${ }^{21}$ See, Constantinides (1979) for details. 
options struck at $\mathrm{K}$, then $\mathrm{c}\left(\mathrm{S}_{\mathrm{T}}\right)=(-) \mathrm{n}\left[\mathrm{S}_{\mathrm{T}}-\mathrm{K}\right]^{+}$. We define by $\mathrm{J}(\mathrm{x}, \mathrm{y}, \mathrm{S}, \mathrm{t})$ the value function at date $t$ of an investor who has a derivatives position paying off $c\left(S_{T}\right)$ at date $T$, and who has endowments $\mathrm{x}$ and $\mathrm{y}$ in the bond and stock accounts, respectively, where $\mathrm{S}$ is the stock price at date $\mathrm{t}$. The endowments $\mathrm{x}$ and $\mathrm{y}$ are net of any cash flows that the investor has incurred at date $\mathrm{t}$ or at an earlier date in acquiring the derivatives position. We stipulate that the investor must hold on to the derivatives position until its expiration. ${ }^{22}$

Formally, we define the value function $\mathrm{J}(\mathrm{x}, \mathrm{y}, \mathrm{S}, \mathrm{t})$ recursively for $\mathrm{t} \leq \mathrm{T}-1$ as

$$
\left.\left.J(x, y, S, t) \equiv \max _{j} E\left[J\left(\left\{x-j-\max \left[k_{1} j,-k_{2} j\right]\right\} R,(y+j) S_{t+1} / S_{t}, t+1\right)\right], S_{t+1}, t+1\right)\right]
$$

and

$$
J(x, y, S, T)=V(x+c(S), y, T)
$$

We denote by $\mathrm{j}_{\mathrm{t}}$ the optimal investment decision at date $\mathrm{t}$. Note that the optimal investment $\mathrm{j}_{\mathrm{t}}$ in the J-problem may well differ from the optimal investment decision $\mathrm{v}_{\mathrm{t}}$ in the $\mathrm{V}$-problem.

In the next section, we derive bounds on the purchase and write prices of derivatives when

\footnotetext{
${ }^{22}$ It may well be suboptimal for the investor to hold on to the derivatives position till its expiration. In deriving the pricing bounds in the next section, we make no assumption to the effect that it is optimal to hold on to the derivatives position until its expiration.
} 
intermediate trading in the bond and stock accounts is permitted and is modeled as in this section.

\section{Option Bounds when Intermediate Trading is Permitted}

We consider an investor who enters date $\mathrm{t}$ with dollar holdings $\mathrm{x}$ in the bond account and $\mathrm{y}$ in the stock account. First, suppose that the investor is not allowed to trade in derivatives at date $t$ and at all future dates. The investor's maximized expected utility of wealth at the terminal date is given by $\mathrm{V}(\mathrm{x}, \mathrm{y}, \mathrm{t})$, where the value function $\mathrm{V}$ is defined in equations (4.4) and (4.5). Next, we enrich the investment opportunity set by introducing a European-style, cash-settled call option that expires at date $\mathrm{T}, \mathrm{T} \leq \mathrm{T}^{\prime}$. Suppose that the investor writes a call option for a cash price $\mathrm{C}$ and invests the proceeds in purchasing $\mathrm{C} /\left(1+\mathrm{k}_{1}\right) \mathrm{S}_{\mathrm{t}}$ shares of stock. The investor's maximized expected utility of wealth at the terminal date is given by $J\left(x, y+C /\left(1+k_{1}\right), S_{t}, t\right)$, where the value function $\mathrm{J}$ is defined in equations (4.6) and (4.7).

The investor's expected utility increases by adopting the zero-net-cost position at date $t$, if and only if $\mathrm{J}\left(\mathrm{x}, \mathrm{y}+\mathrm{C} /\left(1+\mathrm{k}_{1}\right), \mathrm{S}_{\mathrm{t}}, \mathrm{t}\right)>\mathrm{V}(\mathrm{x}, \mathrm{y}, \mathrm{t})$. In equilibrium, the write price of the derivative must be such that $\mathrm{J}\left(\mathrm{x}, \mathrm{y}+\mathrm{C} /\left(1+\mathrm{k}_{1}\right), \mathrm{S}_{\mathrm{t}}, \mathrm{t}\right) \leq \mathrm{V}(\mathrm{x}, \mathrm{y}, \mathrm{t})$. We exploit this condition and derive an upper bound on the reservation write price of the call. We apply a similar argument to derive a lower bound on the reservation purchase price of the call.

The derivation of bounds in the single-period economy in Section 3 relies on the key property 
that the marginal utility is non-increasing in the stock price. This property is obtained under the monotonicity of wealth condition: the wealth at the end of the period, including the payoff of the derivative, is a non-decreasing function of the stock price. This condition, combined with the assumed concavity of the utility function, implies that the marginal utility is non-increasing in the stock price. The monotonicity of wealth condition is guaranteed by judiciously limiting the size of the position in the derivative relative to the stock and bond positions.

In the multiperiod economy, we cannot necessarily satisfy (with probability one) the monotonicity of wealth condition, even if we limit the size of the position in the derivative relative to the stock and bond positions. ${ }^{23}$ The reason is that the optimal trading in the bond and the stock accounts at intermediate dates may result in portfolio positions that violate the monotonicity of wealth condition. Whereas it is easy to generate examples that violate the condition, the probability of such a violation can be made arbitrarily small, by increasing the investor's wealth at the initial date t, relative to the size of the position in the derivative.

Without loss of generality, in all the propositions below, we assume that the investor trading in options buys or writes exactly one option, $\mathrm{n}=1$. We also assume that the investor's wealth is sufficiently large so that the probability of violation of the monotonicity of wealth condition is arbitrarily small.

\footnotetext{
${ }^{23}$ This problem is addressed formally in Constantinides and Zariphopoulou $(1999,2001)$, by limiting the set of admissible policies.
} 
Proposition 1: Under the assumptions of the multiperiod economy, at any time t prior to the option expiration, the reservation write price of a call option is bounded above by $\bar{C}_{1}\left(\mathrm{~S}_{\mathrm{t}}, \mathrm{t}\right)$, where

$$
\bar{C}_{1}\left(\mathrm{~S}_{\mathrm{t}}, \mathrm{t}\right)=\left\{\left(1+\mathrm{k}_{1}\right) /\left(1-\mathrm{k}_{2}\right)\right\} \mathrm{E}\left[\left(\mathrm{S}_{\mathrm{T}}-\mathrm{K}\right)^{+} \mid \mathrm{S}_{\mathrm{t}}\right] / \mathrm{R}_{\mathrm{S}}^{\mathrm{T}-\mathrm{t}} .
$$

Proof: We write $\bar{C}_{1}\left(\mathrm{~S}_{\mathrm{t}}, \mathrm{t}\right)$ as $\bar{C}_{1}(\mathrm{t})$ for short. It suffices to prove that

$$
\Delta_{\mathrm{t}} \equiv \mathrm{J}\left(\mathrm{x}, \mathrm{y}+\bar{C}_{1}(\mathrm{t}) /\left(1+\mathrm{k}_{1}\right), \mathrm{S}_{\mathrm{t}}, \mathrm{t}\right)-\mathrm{V}(\mathrm{x}, \mathrm{y}, \mathrm{t}) \geq 0, \quad \mathrm{t} \leq \mathrm{T} .
$$

If indeed equation (5.2) holds at date $t$, we consider the zero-net-cost policy of writing a call option for cash price of $\bar{C}_{1}(\mathrm{t})$ and investing the proceeds in purchasing $\bar{C}_{1}(\mathrm{t}) /\left(1+\mathrm{k}_{1}\right) \mathrm{S}_{\mathrm{t}}$ shares of stock. The increase in the investor's expected utility is $\Delta_{\mathrm{t}}$ and is positive, by equation (5.2). Therefore, the investor's reservation write price is bounded above by $\bar{C}_{1}(\mathrm{t})$ and the proposition follows.

The proof of equation (5.2) is by induction. Equation (5.2) holds at $t=\mathrm{T}$ because

$$
\begin{aligned}
\Delta_{\mathrm{T}} & =\mathrm{J}\left(\mathrm{x}, \mathrm{y}+\bar{C}_{1}(\mathrm{~T}) /\left(1+\mathrm{k}_{1}\right), \mathrm{S}_{\mathrm{T}}, \mathrm{T}\right)-\mathrm{V}(\mathrm{x}, \mathrm{y}, \mathrm{T}) \\
& =\mathrm{V}\left(\mathrm{x}-\left(\mathrm{S}_{\mathrm{T}}-\mathrm{K}\right)^{+}, \mathrm{y}+\bar{C}_{1}(\mathrm{~T}) /\left(1+\mathrm{k}_{1}\right), \mathrm{T}\right)-\mathrm{V}(\mathrm{x}, \mathrm{y}, \mathrm{T})
\end{aligned}
$$




$$
\begin{aligned}
& \geq \mathrm{V}\left(\mathrm{x}-\left(\mathrm{S}_{\mathrm{T}}-\mathrm{K}\right)^{+}+\left(1-\mathrm{k}_{2}\right) \bar{C}_{1}(\mathrm{~T}) /\left(1+\mathrm{k}_{1}\right), \mathrm{y}, \mathrm{T}\right)-\mathrm{V}(\mathrm{x}, \mathrm{y}, \mathrm{T}) \\
& \geq 0
\end{aligned}
$$

by the definition of $\bar{C}_{1}(\mathrm{~T})$. Finally, we assume that equation (5.2) holds for some $\mathrm{t}, \mathrm{t} \leq \mathrm{T}$ and prove that it holds for $\mathrm{t}-1$ also. Let $\mathrm{v}_{\mathrm{t}-1}$ be the optimal investment decision at date $\mathrm{t}-1$ for the investor who does not trade in the derivative. Then

$$
\begin{aligned}
& \Delta_{\mathrm{t}-1}=\mathrm{J}\left(\mathrm{x}, \mathrm{y}+\bar{C}_{1}(\mathrm{t}-1) /\left(1+\mathrm{k}_{1}\right), \mathrm{S}_{\mathrm{t}-1}, \mathrm{t}-1\right)-\mathrm{V}(\mathrm{x}, \mathrm{y}, \mathrm{t}-1) \\
& \geq \mathrm{E}\left[\mathrm{J}\left(\left\{\mathrm{x}-\mathrm{v}_{\mathrm{t}-1}-\max \left[\mathrm{k}_{1} \mathrm{v}_{\mathrm{t}-1},-\mathrm{k}_{2} \mathrm{~V}_{\mathrm{t}-1}\right]\right\} \mathrm{R},\left\{\mathrm{y}+\mathrm{v}_{\mathrm{t}-1}+\mathrm{E}\left[\left(\mathrm{S}_{\mathrm{T}}-\mathrm{K}\right)^{+} \mid \mathrm{S}_{\mathrm{t}-1}\right] /\left(1-\mathrm{k}_{2}\right) \mathrm{R}_{\mathrm{S}}^{\mathrm{T}-\mathrm{t}+1}\right\} \mathrm{S}_{\mathrm{t}} / \mathrm{S}_{\mathrm{t}-1}, \mathrm{~S}_{\mathrm{t}}, \mathrm{t}\right)\right. \\
& \left.\left.\quad-\mathrm{V}\left(\left\{\mathrm{x}-\mathrm{v}_{\mathrm{t}-1}-\max \left[\mathrm{k}_{1} \mathrm{v}_{\mathrm{t}-1},-\mathrm{k}_{2} \mathrm{~V}_{\mathrm{t}-1}\right]\right\} \mathrm{R},\left(\mathrm{y}+\mathrm{v}_{\mathrm{t}-1}\right) \mathrm{S}_{\mathrm{t}} / \mathrm{S}_{\mathrm{t}-1}\right), \mathrm{t}\right) \mid \mathrm{S}_{\mathrm{t}-1}\right]
\end{aligned}
$$

by the definition of the functions $\mathrm{V}$ and $\mathrm{J}$ and the fact that $\mathrm{v}_{\mathrm{t}-1}$ is the optimal investment decision for the V-problem but not necessarily for the J-problem,

$$
\begin{gathered}
\geq \mathrm{E}\left[\mathrm { V } \left(\left\{\mathrm{x}-\mathrm{v}_{\mathrm{t}-1}-\max \left[\mathrm{k}_{1} \mathrm{v}_{\mathrm{t}-1},-\mathrm{k}_{2} \mathrm{v}_{\mathrm{t}-1}\right]\right\} \mathrm{R},\left\{\mathrm{y}+\mathrm{v}_{\mathrm{t}-1}+\mathrm{E}\left[\left(\mathrm{S}_{\mathrm{T}}-\mathrm{K}\right)^{+} \mid \mathrm{S}_{\mathrm{t}-1}\right] /\left(1-\mathrm{k}_{2}\right) \mathrm{R}_{\mathrm{S}}^{\mathrm{T}-\mathrm{t}+1}\right\} \mathrm{S}_{\mathrm{t}} / \mathrm{S}_{\mathrm{t}-1}-\right.\right. \\
\left.\left.\left.\bar{C}_{1}(\mathrm{t}) /\left(1+\mathrm{k}_{1}\right), \mathrm{t}\right)-\mathrm{V}\left(\left\{\mathrm{x}-\mathrm{v}_{\mathrm{t}-1}-\max \left[\mathrm{k}_{1} \mathrm{v}_{\mathrm{t}-1},-\mathrm{k}_{2} \mathrm{~V}_{\mathrm{t}-1}\right]\right\} \mathrm{R},\left(\mathrm{y}+\mathrm{v}_{\mathrm{t}-1}\right) \mathrm{S}_{\mathrm{t}} / \mathrm{S}_{\mathrm{t}-1}\right), \mathrm{t}\right) \mid \mathrm{S}_{\mathrm{t}-1}\right],
\end{gathered}
$$


by the assumption that equation (5.2) holds for $t$,

$$
\geq \mathrm{E}\left[\mathrm{V}_{\mathrm{y}}\left(\left\{\mathrm{E}\left[\left(\mathrm{S}_{\mathrm{T}}-\mathrm{K}\right)^{+} \mid \mathrm{S}_{\mathrm{t}-1}\right] /\left(1-\mathrm{k}_{2}\right) \mathrm{R}_{\mathrm{S}}^{\mathrm{T}-\mathrm{t}+1}\right\} \mathrm{S}_{\mathrm{t}} / \mathrm{S}_{\mathrm{t}-1}-\bar{C}_{1}(\mathrm{t}) /\left(1+\mathrm{k}_{1}\right)\right) \mid \mathrm{S}_{\mathrm{t}-1}\right]
$$

by the concavity of the function $\mathrm{V}$, where the expression $\mathrm{V}_{\mathrm{y}}$ denotes the partial derivative of $\mathrm{V}\left(\left\{\mathrm{x}-\mathrm{v}_{\mathrm{t}-1}-\max \left[\mathrm{k}_{1} \mathrm{~V}_{\mathrm{t}-1},-\mathrm{k}_{2} \mathrm{~V}_{\mathrm{t}-1}\right]\right\} \mathrm{R},\left\{\mathrm{y}+\mathrm{v}_{\mathrm{t}-1}+\mathrm{E}\left[\left(\mathrm{S}_{\mathrm{T}}-\mathrm{K}\right)^{+} \mid \mathrm{S}_{\mathrm{t}-1}\right] /\left(1-\mathrm{k}_{2}\right) \mathrm{R}_{\mathrm{S}}^{\mathrm{T}-\mathrm{t}+1}\right\} \mathrm{S}_{\mathrm{t}} / \mathrm{S}_{\mathrm{t}-1}-\bar{C}_{1}(\mathrm{t}) /\left(1+\mathrm{k}_{1}\right)\right.$, $\mathrm{S}_{\mathrm{t}}, \mathrm{t}$ ) with respect to its second argument,

$$
\geq E\left[V_{y} h\left(S_{t}\right) \mid S_{t-1}\right]
$$

where,

$$
\mathrm{h}\left(\mathrm{S}_{\mathrm{t}}\right) \equiv\left\{\mathrm{E}\left[\left(\mathrm{S}_{\mathrm{T}}-\mathrm{K}\right)^{+} \mid \mathrm{S}_{\mathrm{t}-1}\right] /\left(1-\mathrm{k}_{2}\right) \mathrm{R}_{\mathrm{S}}^{\mathrm{T}-\mathrm{t}+1}\right\} \mathrm{S}_{\mathrm{t}} / \mathrm{S}_{\mathrm{t}-1}-\bar{C}_{1}(\mathrm{t}) /\left(1+\mathrm{k}_{1}\right)
$$

Note that $E\left[h\left(S_{t}\right) \mid S_{t-1}\right]=0$, by the definition of $\bar{C}_{1}(\mathrm{t})$. Note also that

$$
\mathrm{h}(\mathrm{S})>0 \quad \text { as } \mathrm{S}>\hat{S}
$$

where the stock price $\hat{S}$ is uniquely defined by $h(\hat{S})=0$ and $\hat{S}>0 .{ }^{24}$

${ }^{24}$ We prove the last statement as follows. First, we note that $\left[\partial \bar{C}_{1}(\mathrm{t}) / \partial \mathrm{S}_{\mathrm{t}}\right] /\left(1+\mathrm{k}_{1}\right)$ is increasing, tends to zero for $\mathrm{S}_{\mathrm{t}} \rightarrow 0$, and tends to $1 /\left(1-\mathrm{k}_{2}\right)$ for $\mathrm{S}_{\mathrm{t}} \rightarrow \infty$. Second, $0<\left\{\mathrm{E}\left[\left(\mathrm{S}_{\mathrm{T}}-\mathrm{K}\right)^{+} \mid \mathrm{S}_{\mathrm{t}-1}\right] /\left(1-\mathrm{k}_{2}\right) \mathrm{R}_{\mathrm{S}}^{\mathrm{T}-\mathrm{t}+1}\right\} / \mathrm{S}_{\mathrm{t}-1}<1 /\left(1-\mathrm{k}_{2}\right)$ because $0<$ 
Note also that $\mathrm{V}_{\mathrm{y}}$ is decreasing in $\mathrm{y}$ because $\mathrm{V}$ is a concave function of the dollar value in the stock account. Also, $\left\{\mathrm{y}+\mathrm{v}_{\mathrm{t}-1}+\mathrm{E}\left[\left(\mathrm{S}_{\mathrm{T}}-\mathrm{K}\right)^{+} \mid \mathrm{S}_{\mathrm{t}-1}\right] /\left(1-\mathrm{k}_{2}\right) \mathrm{R}_{\mathrm{S}}^{\mathrm{T}-\mathrm{t}+1}\right\} \mathrm{S}_{\mathrm{t}} / \mathrm{S}_{\mathrm{t}-1}-\bar{C}_{1}(\mathrm{t}) /\left(1+\mathrm{k}_{1}\right)$ is increasing in the stock price $\mathrm{S}_{\mathrm{t}}$, by the monotonicity of wealth assumption. Therefore, $\mathrm{V}_{\mathrm{y}}$ is decreasing in $\mathrm{S}_{\mathrm{t}}$. Equation (5.5), (5.6) and the fact that $\mathrm{V}_{\mathrm{y}}$ is decreasing in $\mathrm{S}_{\mathrm{t}}$ imply

$$
\Delta_{\mathrm{t}-1} \geq \mathrm{V}_{\mathrm{y}}\left(\text { at } \mathrm{S}_{\mathrm{t}}=\hat{S}\right) \mathrm{E}\left[\mathrm{h}\left(\mathrm{S}_{\mathrm{t}}\right) \mid \mathrm{S}_{\mathrm{t}-1}\right]
$$

$\geq 0$.

The proposition states that the single-period bound under transaction costs, $\bar{C}_{1}$, remains valid in a multiperiod context, subject to the monotonicity assumption of the wealth in the stock price during the successive portfolio revisions in the interval $[\mathrm{t}, \mathrm{T}]$. This is an important result because the bound is invariant to the number of trading dates allowed over the life of the option. Furthermore, the calculation of the bound $\bar{C}_{1}\left(\mathrm{~S}_{\mathrm{t}}, \mathrm{t}\right)$ is straightforward.

We state below an extension of the second single-period bound under transaction costs, $\bar{C}_{2}$, to a multiperiod context.

$\mathrm{E}\left[\left(\mathrm{S}_{\mathrm{T}}-\mathrm{K}\right)^{+} \mid \mathrm{S}_{\mathrm{t}-1}\right] / \mathrm{E}\left[\mathrm{S}_{\mathrm{T}} \mid \mathrm{S}_{\mathrm{t}-1}\right]<1$. Since $\mathrm{h}(0)=0$ and the slope of $\mathrm{h}\left(\mathrm{S}_{\mathrm{t}}\right)$ is initially positive and eventually negative, we conclude that $h\left(S_{t}\right)=0$ has exactly one second root for $S_{t}>0$. 


$$
\bar{C}_{2}\left(\mathrm{~S}_{\mathrm{t}}, \mathrm{t}\right)=\left[\left(1+\mathrm{k}_{1}\right) /\left(1-\mathrm{k}_{2}\right)\right]^{\mathrm{T}-\mathrm{t}} \mathrm{E}\left[\left(\mathrm{S}_{\mathrm{T}}-\mathrm{K}\right)^{+} \mid \mathrm{S}_{\mathrm{t}}\right] / \mathrm{R}^{\mathrm{T}-\mathrm{t}} .
$$

The proof is omitted because it is a simplified version of the proof of Proposition 2, which is presented in the appendix. If the length of time between trading dates is "a" instead of one, then equation (5.8) becomes

$$
\bar{C}_{2}\left(\mathrm{~S}_{\mathrm{t}}, \mathrm{t}\right)=\left[\left(1+\mathrm{k}_{1}\right) /\left(1-\mathrm{k}_{2}\right)\right]^{(\mathrm{T}-\mathrm{t}) / \mathrm{a}} \mathrm{E}\left[\left(\mathrm{S}_{\mathrm{T}}-\mathrm{K}\right)^{+} \mid \mathrm{S}_{\mathrm{t}}\right] / \mathrm{R}^{\mathrm{T}-\mathrm{t}}
$$

The bound $\bar{C}_{1}\left(\mathrm{~S}_{\mathrm{t}}, \mathrm{t}\right)$ dominates the bound $\bar{C}_{2}\left(\mathrm{~S}_{\mathrm{t}}, \mathrm{t}\right)$ even when the length of time between trading dates is T-t. ${ }^{25}$ The bound $\bar{C}_{2}\left(\mathrm{~S}_{\mathrm{t}}, \mathrm{t}\right)$ increases and tends to infinity, as the length of time between trading dates decreases. In the next proposition, we state another extension of the second singleperiod bound, $\bar{C}_{2}$, to a multiperiod context. The latter bound is tighter than the bound $\bar{C}_{2}\left(\mathrm{~S}_{\mathrm{t}}, \mathrm{t}\right)$, but requires numerical calculation.

Proposition 2: Under the assumptions of the multiperiod economy, at any time t prior to the option expiration, the reservation write price of a call option is bounded above by $\bar{C}_{3}\left(\mathrm{~S}_{\mathrm{t}}, \mathrm{t}\right)$. $\bar{C}_{3}\left(\mathrm{~S}_{\mathrm{T}}, \mathrm{T}\right)$ is defined as

\footnotetext{
${ }^{25}$ In the single-period economy, the upper bound $\bar{C}_{2}\left(\mathrm{~S}_{\mathrm{t}}, \mathrm{t}\right)$ is given by equation (3.6) and equals $\mathrm{E}\left[\left(\mathrm{S}_{\mathrm{T}}-\mathrm{K}\right)^{+}\right.$ $\left.\mathrm{S}_{\mathrm{t}}\right] / \mathrm{R}^{\mathrm{T}-\mathrm{t}}$ rather than $\left[\left(1+\mathrm{k}_{1}\right) /\left(1-\mathrm{k}_{2}\right)\right]^{\mathrm{T}-\mathrm{t}} \mathrm{E}\left[\left(\mathrm{S}_{\mathrm{T}}-\mathrm{K}\right)^{+} \mid \mathrm{S}_{\mathrm{t}}\right] / \mathrm{R}^{\mathrm{T}-\mathrm{t}}$. Therefore, in the single-period economy, $\bar{C}_{1}>\bar{C}_{2}$ as $\mathrm{R}^{*}$ $\mathrm{R}$.
} 


$$
\bar{C}_{3}\left(\mathrm{~S}_{\mathrm{T}}, \mathrm{T}\right)=\left(\mathrm{S}_{\mathrm{T}}-\mathrm{K}\right)^{+} .
$$

For $\mathrm{t} \leq \mathrm{T}-1, \bar{C}_{3}\left(\mathrm{~S}_{\mathrm{t}}, \mathrm{t}\right)$ is defined as

$$
\bar{C}_{3}\left(\mathrm{~S}_{\mathrm{t}}, \mathrm{t}\right)=\mathrm{E}\left[\bar{C}_{3}\left(\mathrm{~S}_{\mathrm{t}+1}, \mathrm{t}+1\right) \mathrm{I}\left(\mathrm{S}_{\mathrm{t}+1}-\mathrm{x}\right) \mid \mathrm{S}_{\mathrm{t}}\right] / \operatorname{RE}\left[\mathrm{I}\left(\mathrm{S}_{\mathrm{t}+1}-\mathrm{x}\right) \mid \mathrm{S}_{\mathrm{t}}\right],
$$

where

$$
\begin{aligned}
I(z) & =1 /\left(1+k_{1}\right), \text { if } z \leq 0 \\
& =1 /\left(1-k_{2}\right), \quad \text { if } z>0
\end{aligned}
$$

and $x$ solves the equation

$$
\mathrm{E}\left[\bar{C}_{3}\left(\mathrm{~S}_{\mathrm{t}+1}, \mathrm{t}+1\right) \mathrm{I}\left(\mathrm{S}_{\mathrm{t}+1}-\mathrm{x}\right) \mid \mathrm{S}_{\mathrm{t}}\right] / \mathrm{E}\left[\mathrm{I}\left(\mathrm{S}_{\mathrm{t}+1}-\mathrm{x}\right) \mid \mathrm{S}_{\mathrm{t}}\right]=\bar{C}_{3}(\mathrm{x}, \mathrm{t}+1) .
$$

Proof: See the appendix.

Next, we examine the multiperiod versions of the lower bounds $\underline{\mathrm{C}}_{1}$ and $\underline{\mathrm{C}}_{2}$, given by equations (3.15) and (3.16), respectively. As with the single-period economy, we consider the zero-netcost policy of buying one call option at time $t$, financed by the sale of $g_{t} /\left(1+k_{1}\right)$ shares of stock, 
with $g_{t} \leq 1$ and with the remaining funds invested in the riskless asset ${ }^{26}$. First, we examine the case $g_{t}=1$ for all $\mathrm{t}$.

Proposition 3:27 Under the assumptions of the multiperiod economy, at any time t prior to the option expiration the reservation write price of a call option is bounded below by $\underline{\mathrm{C}}_{1}(\mathrm{t}) . \underline{\mathrm{C}}_{1}(\mathrm{~T}-1)$ is defined as

$$
\underline{\mathrm{C}}_{1}\left(\mathrm{~S}_{\mathrm{T}-1}, \mathrm{~T}-1\right)=\operatorname{Max}\left\{0, \mathrm{E}\left[\left(\mathrm{S}_{\mathrm{T}}-\mathrm{K}\right)^{+} \mid \mathrm{S}_{\mathrm{T}-1}\right] / \mathrm{R}+\mathrm{S}_{\mathrm{T}-1}\left(1-\mathrm{k}_{2}\right) /\left(1+\mathrm{k}_{1}\right)-\mathrm{E}\left[\mathrm{S}_{\mathrm{T}} \mid \mathrm{S}_{\mathrm{T}-1}\right] / \mathrm{R}\right\} .
$$

For $\mathrm{t}<\mathrm{T}-1, \underline{\mathrm{C}}_{1}\left(\mathrm{~S}_{\mathrm{t}}, \mathrm{t}\right)$ is defined as

$$
\begin{aligned}
\underline{\mathrm{C}}_{1}\left(\mathrm{~S}_{\mathrm{t}}, \mathrm{t}\right)=\operatorname{Max}\left\{0, \mathrm{E}\left[\underline{\mathrm{C}}_{1}\left(\mathrm{~S}_{\mathrm{t}+1}, \mathrm{t}+1\right) \mathrm{I}\left(\mathrm{S}_{\mathrm{t}+1}-\mathrm{x}\right) \mid \mathrm{S}_{\mathrm{t}}\right] / \operatorname{RE}\left[\mathrm{I}\left(\mathrm{S}_{\mathrm{t}+1}-\mathrm{x}\right) \mid \mathrm{S}_{\mathrm{t}}\right]\right. \\
\left.+\left(1-\mathrm{k}_{2}\right) /\left(1+\mathrm{k}_{1}\right)\left\{\mathrm{S}_{\mathrm{t}}-\mathrm{E}\left[\mathrm{S}_{\mathrm{t}+1} \mathrm{I}\left(\mathrm{S}_{\mathrm{t}+1}-\mathrm{x}\right) \mid \mathrm{S}_{\mathrm{t}}\right] / \operatorname{RE}\left[\mathrm{I}\left(\mathrm{S}_{\mathrm{t}+1}-\mathrm{x}\right) \mid \mathrm{S}_{\mathrm{t}}\right]\right\}\right\},
\end{aligned}
$$

where the function I(.) is given by (5.11) and $x$ solves the equation

$$
\begin{aligned}
& \left\{\left(1-\mathrm{k}_{2}\right) \mathrm{E}\left[\mathrm{S}_{\mathrm{t}+1} \mathrm{I}\left(\mathrm{S}_{\mathrm{t}+1}-\mathrm{x}\right) \mid \mathrm{S}_{\mathrm{t}}\right] /\left(1+\mathrm{k}_{1}\right)-\mathrm{E}\left[\underline{\mathrm{C}}_{1}\left(\mathrm{~S}_{\mathrm{t}+1}, \mathrm{t}+1\right) \mathrm{I}\left(\mathrm{S}_{\mathrm{t}+1}-\mathrm{x}\right) \mid \mathrm{S}_{\mathrm{t}}\right]\right\} / \mathrm{RE}\left[\mathrm{I}\left(\mathrm{S}_{\mathrm{t}+1}-\mathrm{x}\right) \mid \mathrm{S}_{\mathrm{t}}\right] \\
& =\mathrm{x}\left(1-\mathrm{k}_{2}\right) /\left(1+\mathrm{k}_{1}\right)-\underline{\mathrm{C}}_{1}(\mathrm{x}, \mathrm{t}+1) .
\end{aligned}
$$

\footnotetext{
${ }^{26} \mathrm{We}$ assume that the call price at time $\mathrm{t}$ is less than $\mathrm{S}_{\mathrm{t}}\left(1-\mathrm{k}_{2}\right) /\left(1+\mathrm{k}_{1}\right)$.
} 
The bound $\underline{\mathrm{C}}_{1}\left(\mathrm{~S}_{\mathrm{t}}, \mathrm{t}\right)$ in Proposition 3 is not the tightest available, insofar as the choice of shorting $1 /\left(1+\mathrm{k}_{1}\right)$ shares for every call option purchase may not be optimal. On the other hand, the transformation of cash into shares in the multiperiod economy was done in an efficient manner, as with the upper bound in Proposition 2. This bound $\mathrm{C}_{1}\left(\mathrm{~S}_{\mathrm{t}}, \mathrm{t}\right)$ must be computed numerically, but the computation is similar to that of the upper bound $\bar{C}_{3}$ and does not present any particular problems.

The following result presents a multiperiod version of the bound $\underline{C}_{2}$, which must also be computed numerically. Although this bound does select the shorted shares $g_{t}$ efficiently, it does not transform cash into stock efficiently and, thus, does not necessarily dominate $\underline{\mathrm{C}}_{1}\left(\mathrm{~S}_{\mathrm{t}}, \mathrm{t}\right)$.

Proposition $4:^{28}$ Under the assumptions of the multiperiod economy, a lower bound $\underline{\mathrm{C}}_{2}(\mathrm{t})$ on the reservation purchase price of a call option at any time $t$ prior to option expiration is derived recursively from the expressions

$$
\underline{\mathrm{C}}_{2}\left(\mathrm{~S}_{\mathrm{t}}, \mathrm{t}\right)=\mathrm{E}\left[\underline{\mathrm{C}}_{2}\left(\mathrm{~S}_{\mathrm{t}+1}, \mathrm{t}+1\right) \mid \mathrm{S}_{\mathrm{t}}, \mathrm{S}_{\mathrm{t}+1} \leq \mathrm{S}_{3}(\mathrm{t})\right] / \mathrm{R},
$$

where $\mathrm{S}_{3}(\mathrm{t})$ is defined implicitly for all $\mathrm{t} \leq \mathrm{T}-1$ by

\footnotetext{
${ }^{27}$ The proof is in the appendix of the unabridged version of the paper, available from the authors upon request.

${ }^{28}$ The proof is in the appendix of the unabridged version of the paper, available from the authors upon request.
} 


$$
\left\{\left(1+\mathrm{k}_{1}\right) /\left(1-\mathrm{k}_{2}\right)\right\} \mathrm{E}\left[\mathrm{S}_{\mathrm{t}+1} \mid \mathrm{S}_{\mathrm{t}}, \mathrm{S}_{\mathrm{t}+1} \leq \mathrm{S}_{3}(\mathrm{t})\right]=\mathrm{RS}_{\mathrm{t}}
$$

and

$$
\underline{\mathrm{C}}_{2}\left(\mathrm{~S}_{\mathrm{T}}, \mathrm{T}\right)=\left(\mathrm{S}_{\mathrm{T}}-\mathrm{K}\right)^{+}
$$

Proposition 5 yields the tightest possible lower bound available by our methodology. It combines the optimal choice of $g_{t}$ with the efficient transformation of cash into stock in the multiperiod context. It must be computed numerically and is the most complex to estimate, insofar as it requires the recursive evaluation of the optimal $\mathrm{g}_{\mathrm{t}}$.

Proposition 5: ${ }^{29}$ Under the assumptions of the multiperiod economy, the tightest lower bound $\underline{\mathrm{C}}_{3}(\mathrm{t})$ on the reservation purchase price of a call option at any time t prior to option expiration is derived recursively from the expressions

$$
\underline{\mathrm{C}}_{3}\left(\mathrm{~S}_{\mathrm{T}-1}, \mathrm{~T}-1\right)=\mathrm{E}\left[\left(\mathrm{S}_{\mathrm{T}}-\mathrm{K}\right)^{+} \mid \mathrm{S}_{\mathrm{T}-1}, \mathrm{~S}_{\mathrm{T}} \leq \mathrm{S}_{3}(\mathrm{~T}-1)\right] / \mathrm{R},
$$

where $\mathrm{S}_{3}(\mathrm{~T}-1)$ is defined implicitly by

$$
\left\{\left(1+\mathrm{k}_{1}\right) /\left(1-\mathrm{k}_{2}\right)\right\} \mathrm{E}\left[\mathrm{S}_{\mathrm{T}} \mid \mathrm{S}_{\mathrm{T}-1}, \mathrm{~S}_{\mathrm{T}} \leq \mathrm{S}_{3}(\mathrm{~T}-1)\right]=\mathrm{RS}_{\mathrm{T}-1}
$$

\footnotetext{
${ }^{29}$ The proof is in the appendix of the unabridged version of the paper, available from the authors upon request.
} 
and the shorted stock $\mathrm{g}_{\mathrm{T}-1}\left(\mathrm{~S}_{\mathrm{T}-1}\right)$ is equal to

$$
\mathrm{g}_{\mathrm{T}-1}\left(\mathrm{~S}_{\mathrm{T}-1}\right)=\left[\left(\mathrm{S}_{3}(\mathrm{~T}-1)-\mathrm{K}\right)^{+}-\mathrm{R}_{3}\left(\mathrm{~S}_{\mathrm{T}-1}, \mathrm{~T}-1\right)\right] /\left[\left(1+\mathrm{k}_{1}\right) \mathrm{S}_{3}(\mathrm{~T}-1) /\left(1-\mathrm{k}_{2}\right)-\mathrm{RS}_{\mathrm{T}-1}\right]^{+}
$$

At any time $\mathrm{t}<\mathrm{T}-1$ these expressions become

$$
\begin{aligned}
\underline{\mathrm{C}}_{3}\left(\mathrm{~S}_{\mathrm{t}}, \mathrm{t}\right)=\left\{\mathrm{E}\left[\underline{\mathrm{C}}_{3}\left(\mathrm{~S}_{\mathrm{t}+1}, \mathrm{t}+1\right) \mathrm{I}\left(\mathrm{S}_{\mathrm{t}+1}-\mathrm{x}\right) \mid \mathrm{S}_{\mathrm{t}}, \mathrm{S}_{\mathrm{t}+1} \leq \mathrm{S}_{3}(\mathrm{t})\right]\right. \\
\quad+\left(\mathrm{k}_{1}+\mathrm{k}_{2}\right) \mathrm{E}\left[\mathrm{S}_{\mathrm{t}+1} \mathrm{G}_{\mathrm{t}+1}\left(\mathrm{~S}_{\mathrm{t}+1}, \mathrm{x}\right) \mathrm{I}\left(\mathrm{S}_{\mathrm{t}+1}-\mathrm{x}\right) \mid \mathrm{S}_{\mathrm{t}}, \mathrm{S}_{\mathrm{t}+1}\right. \\
\left.\left.\leq \mathrm{S}_{3}(\mathrm{t})\right] /\left(1+\mathrm{k}_{1}\right)\right\} / \operatorname{RE}\left[\mathrm{I}\left(\mathrm{S}_{\mathrm{t}+1}-\mathrm{x}\right) \mid \mathrm{S}_{\mathrm{t}}, \mathrm{S}_{\mathrm{t}+1} \leq \mathrm{S}_{3}(\mathrm{t})\right]
\end{aligned}
$$

$\mathrm{S}_{3}(\mathrm{t})$ is defined implicitly by the equation

$$
\mathrm{E}\left[\mathrm{S}_{\mathrm{t}+1} \mid \mathrm{S}_{\mathrm{t}}, \mathrm{S}_{\mathrm{t}+1}<\mathrm{S}_{3}(\mathrm{t})\right] /\left(1-\mathrm{k}_{2}\right) \mathrm{E}\left[\mathrm{I}\left(\mathrm{S}_{\mathrm{t}+1}-\mathrm{x}\right) \mid \mathrm{S}_{\mathrm{t}}, \mathrm{S}_{\mathrm{t}+1} \leq \mathrm{S}_{3}(\mathrm{t})\right]=\mathrm{RS}_{\mathrm{t}}
$$

$\mathrm{g}_{\mathrm{t}}\left(\mathrm{S}_{\mathrm{t}}\right)$ is defined implicitly by the equation

$$
\mathrm{R}\left(\mathrm{g}_{\mathrm{t}} \mathrm{S}_{\mathrm{t}} /\left(1+\mathrm{k}_{1}\right)-\underline{\mathrm{C}}_{3}\left(\mathrm{~S}_{\mathrm{t}}, \mathrm{t}\right) /\left(1-\mathrm{k}_{2}\right)\right)+\underline{\mathrm{C}}_{3}\left(\mathrm{~S}_{3}(\mathrm{t}), \mathrm{t}+1\right) /\left(1-\mathrm{k}_{2}\right)-\mathrm{g}_{\mathrm{t}} \mathrm{S}_{3}(\mathrm{t}) /\left(1+\mathrm{k}_{1}\right)=0 ;
$$

I(.) is given by (5.11), with $\mathrm{G}\left(\mathrm{S}_{\mathrm{t}+1}, \mathrm{x}\right) \equiv\left\{\mathrm{g}_{\mathrm{t}+1}\left(\mathrm{~S}_{\mathrm{t}+1}\right)\right.$ for $\mathrm{S}_{\mathrm{t}+1} \leq \mathrm{x}, 0$ for $\left.\mathrm{S}_{\mathrm{t}+1}>\mathrm{x}\right\}$, and with $x$ given implicitly by the equation 


$$
\mathrm{R}\left(\mathrm{g}_{\mathrm{t}} \mathrm{S}_{\mathrm{t}}\left(1-\mathrm{k}_{2}\right) /\left(1+\mathrm{k}_{1}\right)-\underline{\mathrm{C}}_{3}\left(\mathrm{~S}_{\mathrm{t}}, \mathrm{t}\right)\right)=\mathrm{g}_{\mathrm{t}+1}(\mathrm{x}) \mathrm{x}\left(1-\mathrm{k}_{2}\right) /\left(1+\mathrm{k}_{1}\right)-\underline{\mathrm{C}}_{3}(\mathrm{x}, \mathrm{t}+1) .
$$

The dependence of the multiperiod efficient lower bound $\underline{C}_{3}\left(\mathrm{~S}_{\mathrm{t}}, \mathrm{t}\right)$ on the partition of the interval $[t, T]$ is quite complex. On the one hand, each successive partition reduces the bound because of the presence of the transaction costs in (5.22). On the other hand, transaction costs add to the expectation the extra term involving the expectation of $\mathrm{S}_{\mathrm{t}+1} \mathrm{G}_{\mathrm{t}+1}$ in (5.21).

\section{Generalizations}

\subsection{Bounds on Put Prices}

We may use the upper bounds on the write price of a call option, derived in Propositions 1 and 2, to derive upper bounds on the write price of a put option. Let $\bar{C}$ be an upper bound on the reservation write price of a call option, when trading is permitted between the current date $t$ and

the expiration date T. We prove that $\bar{P}$ is an upper bound on the reservation write price of a put option, where

$$
\bar{P}=\bar{C}-\left(1-\mathrm{k}_{2}\right) \mathrm{S}(\mathrm{t}) /\left(1+\mathrm{k}_{1}\right)+\mathrm{K} / \mathrm{R}^{\mathrm{T}-\mathrm{t}} .
$$


To prove it, assume that the put write price equals $\bar{P}$. Then (a) write a put, (b) short $1 /\left(1+\mathrm{k}_{1}\right)$ shares, and (c) lend $\mathrm{K} / \mathrm{R}^{\mathrm{T}-\mathrm{t}}$. The net inflow is $\bar{P}+\left(1-\mathrm{k}_{2}\right) \mathrm{S}(\mathrm{t}) /\left(1+\mathrm{k}_{1}\right)-\mathrm{K} / \mathrm{R}^{\mathrm{T}-\mathrm{t}}$ and equals $\bar{C}$. Also, the net inflow at $\mathrm{T}$ is $-\max [\mathrm{K}-\mathrm{S}(\mathrm{T}), 0]-\mathrm{S}(\mathrm{T})+\mathrm{K}=-\max [\mathrm{S}(\mathrm{T})-\mathrm{K}, 0]$ and equals the net inflow at $\mathrm{T}$ of a short position in a call. The investor's expected utility weakly increases in writing the put. Therefore, $\bar{P}$ is an upper bound on the reservation write price of a put option. This completes the proof.

Likewise, we may use the lower bounds on the purchase price of a call option, derived in Propositions 3-5, to derive lower bounds on the purchase price of a put option. Let $\underline{\mathrm{C}}$ be a lower bound on the reservation purchase price of a call option, when trading is permitted between the current date $\mathrm{t}$ and the expiration date $\mathrm{T}$. We prove that $\underline{\mathrm{P}}$ is a lower bound on the reservation write price of a put option, where

$$
\underline{\mathrm{P}}=\underline{\mathrm{C}}-\left(1+\mathrm{k}_{1}\right) \mathrm{S}(\mathrm{t}) /\left(1-\mathrm{k}_{2}\right)+\mathrm{K} / \mathrm{R}^{\mathrm{T}-\mathrm{t}}
$$

To prove it, assume that the put purchase price equals $\underline{P}$. Then (a) buy a put, (b) buy $1 /\left(1-k_{2}\right)$ shares, and (c) borrow $\mathrm{K} / \mathrm{R}^{\mathrm{T}-\mathrm{t}}$. The net outflow is $\underline{\mathrm{P}}+\left(1+\mathrm{k}_{1}\right) \mathrm{S}(\mathrm{t}) /\left(1-\mathrm{k}_{2}\right)-\mathrm{K} / \mathrm{R}^{\mathrm{T}-\mathrm{t}}$ and equals C. Also, the net inflow at $\mathrm{T}$ is $\max [\mathrm{K}-\mathrm{S}(\mathrm{T}), 0]+\mathrm{S}(\mathrm{T})+\mathrm{K}=\max [\mathrm{S}(\mathrm{T})-\mathrm{K}, 0]$ and equals the net inflow at $\mathrm{T}$ of a long position in a call. The investor's expected utility weakly increases in buying the put. Therefore, $\underline{\mathrm{P}}$ is a lower bound on the reservation purchase price of a put option. This completes the proof. 
The bounds on the price of a put, expressed in equations (6.1) and (6.2), are weak because they introduce the round-trip transaction cost in trading one share of stock. Alternatively, we may derive directly upper and lower bounds on the reservation prices of puts by replicating the methods employed in deriving Propositions 1-5. We report below, without proof, just one of these results. It is a lower bound on the reservation purchase price of a put option. It has the distinguishing feature, along with Proposition 1, that it is independent of the trading frequency. Furthermore, it is easy to compute.

Proposition 6: Under the assumptions of the multiperiod economy, at any time t prior to the option expiration, the reservation purchase price of a put option is bounded below by $\underline{\mathrm{P}}\left(\mathrm{S}_{\mathrm{t}}, \mathrm{t}\right)$, where

$$
\underline{\mathrm{P}}\left(\mathrm{S}_{\mathrm{t}}, \mathrm{t}\right)=\left(1-\mathrm{k}_{2}\right) E\left[\left(\mathrm{~K}-\mathrm{S}_{\mathrm{T}}\right)^{+} \mid \mathrm{S}_{\mathrm{t}}\right] /\left(1+\mathrm{k}_{1}\right) \mathrm{R}_{\mathrm{S}}^{\mathrm{T}-\mathrm{t}} .
$$

We may use an upper bound on the write price of a put option, to derive an upper bound on the write price of a call option. We may also use a lower bound on the purchase price of a put option to derive a lower bound on the purchase price of a call option. In particular, the lower bound on the purchase price of a put option in equation (6.3) implies the following lower bound on the reservation purchase price of a call option:

$$
\underline{\mathrm{C}}\left(\mathrm{S}_{\mathrm{t}}, \mathrm{t}\right)=\underline{\mathrm{P}}\left(\mathrm{S}_{\mathrm{t}}, \mathrm{t}\right)+\left(1-\mathrm{k}_{2}\right) \mathrm{S}_{\mathrm{t}} /\left(1+\mathrm{k}_{1}\right)-\mathrm{K} / \mathrm{R}^{\mathrm{T}-\mathrm{t}}
$$




$$
\begin{aligned}
& =\left(1-\mathrm{k}_{2}\right)\left\{\mathrm{E}\left[\left(\mathrm{K}-\mathrm{S}_{\mathrm{T}}\right)^{+} \mid \mathrm{S}_{\mathrm{t}}\right] / \mathrm{R}_{\mathrm{S}}^{\mathrm{T}-\mathrm{t}}+\mathrm{S}_{\mathrm{t}}\right\} /\left(1+\mathrm{k}_{1}\right)-\mathrm{K} / \mathrm{R}^{\mathrm{T}-\mathrm{t}} \\
& =\left(1-\mathrm{k}_{2}\right) \mathrm{E}\left[\left(\mathrm{S}_{\mathrm{T}}-\mathrm{K}\right)^{+} \mid \mathrm{S}_{\mathrm{t}}\right] /\left(1+\mathrm{k}_{1}\right) \mathrm{R}_{\mathrm{S}}^{\mathrm{T}-\mathrm{t}}+\mathrm{K}\left(1-\mathrm{k}_{2}\right) /\left(1+\mathrm{k}_{1}\right) \mathrm{R}_{\mathrm{S}}^{\mathrm{T}-\mathrm{t}}-\mathrm{K} / \mathrm{R}^{\mathrm{T}-\mathrm{t}} .
\end{aligned}
$$

\subsection{Bounds on Options with Physical Delivery}

The bounds derived in this paper apply to cash-settled options. Nonetheless, their extension to options with physical delivery is relatively simple. Consider first the upper bound in Proposition

1. Since the settlement terms affect the option only at date $\mathrm{T}$, it suffices to consider $\bar{C}_{1}\left(\mathrm{~S}_{\mathrm{T}-1}, \mathrm{~T}-\right.$ 1). At date $\mathrm{T}$, the value function $\mathrm{J}\left(\mathrm{x}, \mathrm{y}+\bar{C}_{1}(\mathrm{~T}) /\left(1+\mathrm{k}_{1}\right), \mathrm{S}_{\mathrm{T}}, \mathrm{T}\right)$ is equal to $\mathrm{V}(\mathrm{x}, \mathrm{y}+$ $\left.\bar{C}_{1}(\mathrm{~T}) /\left(1+\mathrm{k}_{1}\right), \mathrm{S}_{\mathrm{T}}, \mathrm{T}\right)$ for $\mathrm{S}_{\mathrm{T}} \leq \mathrm{K} /\left(1+\mathrm{k}_{1}\right)$, and to $\mathrm{V}\left(\mathrm{x}+\mathrm{K}, \mathrm{y}+\bar{C}_{1}(\mathrm{~T}) /\left(1+\mathrm{k}_{1}\right)-\mathrm{S}_{\mathrm{T}}, \mathrm{S}_{\mathrm{T}}, \mathrm{T}\right)$ for $\mathrm{S}_{\mathrm{T}}>$ $\mathrm{K} /\left(1+\mathrm{k}_{1}\right) .{ }^{30}$ The value function is, therefore, greater than or equal to $\mathrm{V}\left(\mathrm{x}, \mathrm{y}+\bar{C}_{1}(\mathrm{~T}) /\left(1+\mathrm{k}_{1}\right)-\right.$ $\left.\left(\mathrm{S}_{\mathrm{T}}\left(1+\mathrm{k}_{1}\right)-\mathrm{K}\right)^{+} /\left(1+\mathrm{k}_{1}\right), \mathrm{S}_{\mathrm{T}}, \mathrm{T}\right)$, which in turn is equal to $\mathrm{V}(\mathrm{x}, \mathrm{y}, \mathrm{T})$, if $\bar{C}_{1}(\mathrm{~T})=\left(\mathrm{S}_{\mathrm{T}}\left(1+\mathrm{k}_{1}\right)-\mathrm{K}\right)^{+}=$ $\left(1+\mathrm{k}_{1}\right)\left(\mathrm{S}_{\mathrm{T}}-\mathrm{K} /\left(1+\mathrm{k}_{1}\right)\right)^{+}$. Hence, for physical delivery options the upper bound $\bar{C}_{1}\left(\mathrm{~S}_{\mathrm{t}}, \mathrm{t}\right)$ is equal to $\left(1+k_{1}\right) E\left[\left(S_{T}-K /\left(1+k_{1}\right)\right)^{+} \mid S_{t}\right] / R_{S}{ }^{T-t}$. Note that this bound is independent of $k_{2}$. A similar relation holds for the bound $\bar{C}_{3}\left(\mathrm{~S}_{\mathrm{T}-1}, \mathrm{~T}-1\right)$, which is equal to $\mathrm{E}\left[\left(\mathrm{S}_{\mathrm{T}}-\mathrm{K} /\left(1+\mathrm{k}_{1}\right)\right)^{+} \mid \mathrm{S}_{\mathrm{T}-1}\right] / \mathrm{R}$, while (5.10)-(5.12) continue to apply for $\mathrm{t}<\mathrm{T}-1$.

\footnotetext{
${ }^{30}$ Under transaction costs the option holders will always exercise the option when $\mathrm{S}_{\mathrm{T}}\left(1-\mathrm{k}_{2}\right) \geq \mathrm{K}$, will always let the option expire when $\mathrm{S}_{\mathrm{T}}\left(1+\mathrm{k}_{1}\right) \leq \mathrm{K}$, and may take either action for $\mathrm{S}_{\mathrm{T}} \in\left(\mathrm{K} /\left(1+\mathrm{k}_{1}\right), \mathrm{K} /\left(1-\mathrm{k}_{2}\right)\right)$; see Perrakis and Lefoll (1997). Here we adopt the most conservative assumption for the option writer, that exercise will take place when $\mathrm{S}_{\mathrm{T}}>\mathrm{K} /\left(1+\mathrm{k}_{1}\right)$.
} 


\section{Numerical Results}

We illustrate the bounds in the case that the interest rate is zero. The dividend yield is assumed zero and the stock price process is a geometric Brownian motion, such that the mean annual equity premium is $4 \%$ and the annual stock volatility is $15 \%$ :

$$
\mathrm{dS}_{\mathrm{t}} / \mathrm{S}_{\mathrm{t}}=0.04 \mathrm{dt}+0.15 \mathrm{dW}_{\mathrm{t}}
$$

where $\mathrm{W}_{\mathrm{t}}$ is a standard Brownian motion on the physical probability measure. ${ }^{31}$ These assumptions respect the constraint in equation (2.1), that the expected rate of return on the stock, gross of transaction costs, exceeds the bond return. We assume that the current stock price is 100. We consider a 3-month, European call option with strike-to-price ratio $\mathrm{K} / \mathrm{S}=0.95,1.00$, and 1.05 .

\footnotetext{
${ }^{31}$ It is only for purposes of illustration that we model the stock price process by a lognormal. An attractive feature of these bounds is that they may be derived for any arbitrary distribution of the stock price, provided that the stock price is bounded below by zero and the first moment exists. In particular, as the trading frequency increases, the stock price process need not converge to the lognormal, but may converge to a mixed diffusion - point process. Even if we were to set the transaction cost rate equal to zero, it is nowhere assumed that the market is either complete or tends to a complete market, as the frequency of trading increases. Thus, the model accommodates stochastic volatility and stock price jumps. Since the market is incomplete, the bounds need not tend to the BlackScholes option price, as the frequency of trading increases, even if the transaction costs rate is set equal to zero.
} 
In Table 1 , we set that the transaction cost rates equal to $1 \%, \mathrm{k}_{1}=\mathrm{k}_{2}=0.01$. In the second row, we present the Black-Scholes call price. The Black-Scholes price of the at-the-money call is 2.99. The hedge ratio of this call is 0.51 . It costs $0.51 \times 100 \times 0.01=0.51$ just to set up the initial hedge, raising the reservation write price to 3.50 , even without allowance for rehedging costs. By contrast, in the third row, we present the stochastic dominance upper bound on the reservation write price of a call option, provided by Proposition 1. Note that this bound is independent of the number of trading dates over the life of the call. The Proposition 1 bound for the at-the-money call is 3.57. The bound is tight. The bound is tight also for the out-of-themoney and the in-the-money call.

In the next three rows, we present the call upper bounds provided by Proposition 2 with trading once every three months, monthly, and biweekly. In almost all cases considered, the bound provided by Proposition 2 is tighter than the bound provided by Proposition 1, but the absolute difference is small. In Proposition 2, the bound becomes tighter as the trading interval decreases, but the absolute difference is small. Overall, both propositions provide tight bounds on the reservation write price. In the same table, we also present the upper bounds in terms of the implied volatility. In all cases, we obtain the standard result that the implied volatility is decreasing in the ratio $\mathrm{K} / \mathrm{S}$. We do not display the lower bounds on the reservation purchase price of a call option, implied by Propositions 3-5, because these bounds are weak, at least for $1 \%$ transaction cost rates.

We present Leland's (1985) reservation write price of a call option, when the trading interval is 
of length $\Delta \mathrm{t}$. The variance is adjusted as

$$
\sigma^{2} \rightarrow \sigma^{2}+\sqrt{\frac{2}{\pi}} \frac{2 \sigma k}{\sqrt{\Delta t}}
$$

and the reservation price is calculated from the Black-Scholes formula. This reservation write price does not reflect the transaction cost incurred initially in setting up the hedged position. In Table 1, we adjust the reservation price to reflect this cost. Even with this adjustment, the comparison between Leland's write price and our upper bound is tenuous for three reasons. First, the Leland write price is designed to take advantage of the properties of the lognormal process. By contrast, our bounds do not take advantage of the lognormal process and, therefore, work for any process. Second, the Leland write price relies on the approximation that the trading interval is short. Third, it ignores the risk incurred by the hedging agent as the result of the variance of the tracking error. This risk is negligible only if the trading interval is short. Thus, we present results for trading intervals of length one day and one week. In all cases, the Leland write price provides weaker bounds than the bounds provided by Propositions 1 and 2 .

In Table 2, we set the transaction cost rates equal to $3 \%, \mathrm{k}_{1}=\mathrm{k}_{2}=0.03$. All other assumptions remain unchanged. As expected, the bounds implied by Propositions 1 and 2 are weaker in the presence of the higher transaction costs, but are still tight. By contrast, the Leland write price provides substantially weaker bounds. In all cases, the implied volatility is decreasing in the ratio $\mathrm{K} / \mathrm{S}$. 
In Table 3, we present a lower bound on the reservation purchase price of a put option implied by Proposition 6 when the transaction cost rates equal $1 \%$ and $3 \%$. Note that this bound is independent of the trading interval. The bound is tight. In the same table, we also present the lower bound in terms of the implied volatility. In all cases, the implied volatility is decreasing in the ratio $\mathrm{K} / \mathrm{S}$.

\section{Concluding Remarks}

We have derived upper and lower bounds on option prices based on the given distribution of the underlying stock return. The distribution of the underlying stock return is consistent with timeseries processes of the stock return that allow for diffusion processes with stochastic volatility, mixtures of lognormal and jump processes, and empirically fitted distributions. Although the bounds were illustrated numerically for the case of lognormal distributions, we stress that the bounds are widely applicable.

The bounds were derived for European options only. An important extension of the methodology presented in this paper would be the derivation of bounds for American options, both put options and call options with dividends. Such an extension presents difficulties, since option writers or holders need to hedge their positions against both immediate and deferred exercise at any point in time. 


\section{APPENDIX: Proof of Proposition 2}

We provide a proof in the case that the probability density function $\mathrm{f}\left(\mathrm{S}_{\mathrm{t}+1} / \mathrm{S}_{\mathrm{t}}\right)$, has its support in $[0, \infty)$, with $f(z)>0$ for $z>0$. The proof is easy also in the case that $f(z)$ has finite support [a, b], with $f(z)>0$ in that interval. First, we prove the following lemma.

Lemma 2.1: The function $\bar{C}_{3}\left(\mathrm{~S}_{\mathrm{t}}, \mathrm{t}\right)$ is increasing and convex in $\mathrm{S}_{\mathrm{t}}$ and $\bar{C}_{3}(0, \mathrm{t})=0$.

Proof: By equation (5.9), the lemma holds at $\mathrm{t}=\mathrm{T}$. The proof proceeds by induction. We assume that the function $\bar{C}_{3}\left(S_{t+1}, t+1\right)$ is increasing and convex in $\mathrm{S}_{\mathrm{t}+1}$, and $\bar{C}_{3}(0, \mathrm{t}+1)=0$. We prove that $\bar{C}_{3}\left(\mathrm{~S}_{\mathrm{t}}, \mathrm{t}\right)$ is increasing and convex in $\mathrm{S}_{\mathrm{t}}$, and $\bar{C}_{3}(0, \mathrm{t})=0$.

We define the functions $\mathrm{g}\left(\mathrm{y}, \mathrm{S}_{\mathrm{t}}\right)$ and $\mathrm{p}\left(\mathrm{y}, \mathrm{S}_{\mathrm{t}}\right)$ as

$$
\mathrm{g}\left(\mathrm{y}, \mathrm{S}_{\mathrm{t}}\right) \equiv \mathrm{E}\left[\bar{C}_{3}\left(\mathrm{~S}_{\mathrm{t}+1}, \mathrm{t}+1\right) \mathrm{I}\left(\mathrm{S}_{\mathrm{t}+1}-\mathrm{y}\right) \mid \mathrm{S}_{\mathrm{t}}\right]
$$

and

$$
\mathrm{p}\left(\mathrm{y}, \mathrm{S}_{\mathrm{t}}\right) \equiv \operatorname{RE}\left[\mathrm{I}\left(\mathrm{S}_{\mathrm{t}+1}-\mathrm{y}\right) \mid \mathrm{S}_{\mathrm{t}}\right]
$$

where the function $\mathrm{I}(\cdot)$ is defined in equation (5.11). By direct differentiation, we obtain 


$$
\mathrm{g}^{\prime} \equiv \partial \mathrm{g}\left(\mathrm{y}, \mathrm{S}_{\mathrm{t}}\right) / \partial \mathrm{y}=\left\{\left(1+\mathrm{k}_{1}\right)^{-1}-\left(1-\mathrm{k}_{2}\right)^{-1}\right\} \mathrm{f}\left(\mathrm{y} / \mathrm{S}_{\mathrm{t}}\right) \mathrm{S}_{\mathrm{t}}^{-1} \bar{C}_{3}(\mathrm{y}, \mathrm{t}+1)
$$

and

$$
\mathrm{p}^{\prime} \equiv \partial \mathrm{p}\left(\mathrm{y}, \mathrm{S}_{\mathrm{t}}\right) / \partial \mathrm{y}=\mathrm{R}\left\{\left(1+\mathrm{k}_{1}\right)^{-1}-\left(1-\mathrm{k}_{2}\right)^{-1}\right\} \mathrm{f}\left(\mathrm{y} / \mathrm{S}_{\mathrm{t}}\right) \mathrm{S}_{\mathrm{t}}^{-1}
$$

Note that $\mathrm{g}^{\prime} / \mathrm{p}^{\prime}=\bar{C}_{3}(\mathrm{y}, \mathrm{t}+1) / \mathrm{R}$. We also write

$$
\begin{aligned}
\mathrm{D}\left(\mathrm{y}, \mathrm{S}_{\mathrm{t}}\right) \equiv \partial\left\{\mathrm{g}\left(\mathrm{y}, \mathrm{S}_{\mathrm{t}}\right) / \mathrm{p}\left(\mathrm{y}, \mathrm{S}_{\mathrm{t}}\right)\right\} / \partial \mathrm{y} & =\left\{\mathrm{p} \mathrm{g}^{\prime}-\mathrm{g} \mathrm{p}^{\prime}\right\} / \mathrm{p}^{2} \\
& =\left\{-\mathrm{p}^{\prime} / \mathrm{p}\right\}\left\{\mathrm{g} / \mathrm{p}-\bar{C}_{3}(\mathrm{y}, \mathrm{t}+1) / \mathrm{R}\right\}, \text { if } \mathrm{f}(\cdot)>0
\end{aligned}
$$

The sign of $\mathrm{D}$ is the same as the sign of $\mathrm{g} / \mathrm{p}-\bar{C}_{3}(\mathrm{y}, \mathrm{t}+1) / \mathrm{R}$, because $-\mathrm{p}^{\prime} / \mathrm{p}$ is positive. We prove that there exists some $\mathrm{x}, \mathrm{x}>0$, such that $\mathrm{D}\left(\mathrm{x}, \mathrm{S}_{\mathrm{t}}\right)=0$, by showing that there exists some $\varepsilon, \varepsilon>0$, such that $\mathrm{D}\left(\varepsilon, \mathrm{S}_{\mathrm{t}}\right)>0$; and that $\mathrm{D}\left(\mathrm{y}, \mathrm{S}_{\mathrm{t}}\right)$ is negative for sufficiently large $\mathrm{y}$. First, we note that $\mathrm{g} / \mathrm{p}>0$. Second, we note $\bar{C}_{3}(\mathrm{y}, \mathrm{t}+1)$ tends to zero, as y tends to zero, by assumption. Therefore, there exists an $\varepsilon, \varepsilon>0$, such that $\mathrm{D}\left(\varepsilon, \mathrm{S}_{\mathrm{t}}\right)>0$.

We prove that $\mathrm{D}\left(\mathrm{y}, \mathrm{S}_{\mathrm{t}}\right)$ is negative for sufficiently large $\mathrm{y}$. The function $\mathrm{g} / \mathrm{p}$ is bounded from above, as y tends to infinity because 


$$
\mathrm{g}\left(\mathrm{y}, \mathrm{S}_{\mathrm{t}}\right) / \mathrm{p}\left(\mathrm{y}, \mathrm{S}_{\mathrm{t}}\right) \leq \frac{\max y g\left(y, S_{\mathrm{t}}\right)}{\min _{y} p\left(y, S_{t}\right)}=\left(\frac{1+k_{1}}{1-k_{2}}\right) \mathrm{E}\left[\bar{C}_{3}\left(\mathrm{~S}_{\mathrm{t}+1}, \mathrm{t}+1\right) \mid \mathrm{S}_{\mathrm{t}}\right]
$$

The function $\bar{C}_{3}(\mathrm{y}, \mathrm{t}+1)$ is unbounded from above, by assumption. Therefore, there exists some $x, x>0$, such that $D\left(x, S_{t}\right)=0$, thereby identifying a local maximum of the function $g\left(y, S_{t}\right) / p(y$, $\mathrm{S}_{\mathrm{t}}$ ) with respect to $\mathrm{y}$. The next task is to prove that the local maximum is unique and is a global maximum for $\mathrm{y} \geq 0$.

Suppose that there exists a number $\mathrm{x}^{\prime}$, such that $\mathrm{x}^{\prime}>\mathrm{x}$, and $\mathrm{x}^{\prime}$ is the smallest value of $\mathrm{y}$ such that $\mathrm{D}\left(\mathrm{y}, \mathrm{S}_{\mathrm{t}}\right)=0$. Then $\mathrm{D}\left(\mathrm{x}^{\prime}-\varepsilon, \mathrm{S}_{\mathrm{t}}\right)<0$ for some $\varepsilon>0$. However, $\mathrm{g}\left(\mathrm{x}^{\prime}, \mathrm{S}_{\mathrm{t}}\right) / \mathrm{p}\left(\mathrm{x}^{\prime}, \mathrm{S}_{\mathrm{t}}\right)<\mathrm{g}\left(\mathrm{x}^{\prime}-\varepsilon\right.$, $\left.\mathrm{S}_{\mathrm{t}}\right) / \mathrm{p}\left(\mathrm{x}^{\prime}-\varepsilon, \mathrm{S}_{\mathrm{t}}\right)$, because $\mathrm{g} / \mathrm{p}$ attains a local minimum at $\mathrm{y}=\mathrm{x}^{\prime}$. Also, $\bar{C}_{3}\left(\mathrm{x}^{\prime}-\varepsilon, \mathrm{t}+1\right)<\bar{C}_{3}\left(\mathrm{x}^{\prime}\right.$, $\mathrm{t}+1)$, because $\bar{C}_{3}(\mathrm{y}, \mathrm{t}+1)$ is increasing in y, by assumption. Therefore

$$
\begin{aligned}
\mathrm{D}\left(\mathrm{x}^{\prime}-\varepsilon, \mathrm{S}_{\mathrm{t}}\right) & =\mathrm{g}\left(\mathrm{x}^{\prime}-\varepsilon, \mathrm{S}_{\mathrm{t}}\right) / \mathrm{p}\left(\mathrm{x}^{\prime}-\varepsilon, \mathrm{S}_{\mathrm{t}}\right)-\bar{C}_{3}\left(\mathrm{x}^{\prime}-\varepsilon, \mathrm{t}+1\right) \\
& >\mathrm{g}\left(\mathrm{x}^{\prime}, \mathrm{S}_{\mathrm{t}}\right) / \mathrm{p}\left(\mathrm{x}^{\prime}, \mathrm{S}_{\mathrm{t}}\right)-\bar{C}_{3}\left(\mathrm{x}^{\prime}, \mathrm{t}+1\right) \\
& >0
\end{aligned}
$$

which is a contradiction. We conclude that the function $\mathrm{g} / \mathrm{h}$ attains a global maximum for $\mathrm{y}>0$ at $\mathrm{y}=\mathrm{x}$, where $\mathrm{x}$ is the unique root of $\mathrm{D}\left(\mathrm{y}, \mathrm{S}_{\mathrm{t}}\right)=0$. The global maximum is given by 


$$
\mathrm{g}\left(\mathrm{x}, \mathrm{S}_{\mathrm{t}}\right) / \mathrm{p}\left(\mathrm{x}, \mathrm{S}_{\mathrm{t}}\right)=\bar{C}_{3}(\mathrm{x}, \mathrm{t}+1) / \mathrm{R}
$$

From the definition of $\bar{C}_{3}\left(\mathrm{~S}_{\mathrm{t}}, \mathrm{t}\right)$ in equation (5.10), we conclude that

$$
\bar{C}_{3}\left(\mathrm{~S}_{\mathrm{t}}, \mathrm{t}\right)=\mathrm{g}\left(\mathrm{x}, \mathrm{S}_{\mathrm{t}}\right) / \mathrm{p}\left(\mathrm{x}, \mathrm{S}_{\mathrm{t}}\right)
$$

We proceed to show that $\bar{C}_{3}\left(\mathrm{~S}_{\mathrm{t}}, \mathrm{t}\right)$ is increasing and convex in $\mathrm{S}_{\mathrm{t}}$. By equation (A.9), $\bar{C}_{3}\left(\mathrm{~S}_{\mathrm{t}}, \mathrm{t}\right)$ is the value of $g\left(y, S_{t}\right) / h\left(y, S_{t}\right)$, maximized over $y$. We define the variables $z=S_{t+1} / S_{t}$ and w $=y / S_{t}$ and write

$$
\begin{aligned}
\bar{C}_{3}\left(\mathrm{~S}_{\mathrm{t}}, \mathrm{t}\right) & =\max _{\mathrm{y}} \mathrm{g}\left(\mathrm{y}, \mathrm{S}_{\mathrm{t}}\right) / \mathrm{p}\left(\mathrm{y}, \mathrm{S}_{\mathrm{t}}\right) \\
& =\max _{\mathrm{w}} \mathrm{E}\left[\bar{C}_{3}\left(\mathrm{~S}_{\mathrm{t}} \mathrm{z}, \mathrm{t}+1\right) \mathrm{I}(\mathrm{z}-\mathrm{w})\right] / \mathrm{RE}[\mathrm{I}(\mathrm{z}-\mathrm{w})],
\end{aligned}
$$

where the expectation is taken over the random variable $\mathrm{z}$ that has probability density $\mathrm{f}(\mathrm{z})$. After taking the expectation, the maximand is a function of $\mathrm{S}_{\mathrm{t}}$ and $\mathrm{w}$. Conditional on $\mathrm{w}$, the maximand is an increasing and convex function of $\mathrm{S}_{\mathrm{t}}$. These properties are preserved under the operation of maximization with respect to w. Therefore, $\bar{C}_{3}\left(\mathrm{~S}_{\mathrm{t}}, \mathrm{t}\right)$ is increasing and convex in $\mathrm{S}_{\mathrm{t}}$. Finally, $\bar{C}_{3}(0, \mathrm{t})=0$ because $\mathrm{g}(\mathrm{x}, 0) / \mathrm{p}(\mathrm{x}, 0)=0$. 
Lemma 2.2:

$$
E\left[h\left(S_{t}, S_{t+1}, t\right) \mid S_{t}\right]=0
$$

where,

$$
\mathrm{h}\left(\mathrm{S}_{\mathrm{t}}, \mathrm{S}_{\mathrm{t}+1}, \mathrm{t}\right) \equiv\left\{\bar{C}_{3}\left(\mathrm{~S}_{\mathrm{t}}, \mathrm{t}\right) \mathrm{R}-\bar{C}_{3}\left(\mathrm{~S}_{\mathrm{t}+1}, \mathrm{t}+1\right)\right\} \mathrm{I}\left(-\bar{C}_{3}\left(\mathrm{~S}_{\mathrm{t}}, \mathrm{t}\right) \mathrm{R}+\bar{C}_{3}\left(\mathrm{~S}_{\mathrm{t}+1}, \mathrm{t}+1\right)\right)
$$

Proof: By Lemma 2.1 and equations (5.10) and (5.12), there exists a unique number $\mathrm{x}, \mathrm{x}>0$, such that $\bar{C}_{3}\left(\mathrm{~S}_{\mathrm{t}}, \mathrm{t}\right) \mathrm{R}-\bar{C}_{3}(\mathrm{x}, \mathrm{t}+1)=0$. By the monotonicity of $\bar{C}_{3}(\mathrm{x}, \mathrm{t}+1)$ in x, we obtain that $\bar{C}_{3}\left(\mathrm{~S}_{\mathrm{t}}, \mathrm{t}\right) \mathrm{R}-\bar{C}_{3}\left(\mathrm{~S}_{\mathrm{t}+1}, \mathrm{t}+1\right)>0$, as $\mathrm{S}_{\mathrm{t}+1}>\mathrm{x}$. Therefore, by equation $(5.10)$

$$
\begin{aligned}
\mathrm{E}\left[\mathrm{h}\left(\mathrm{S}_{\mathrm{t}}, \mathrm{S}_{\mathrm{t}+1}, \mathrm{t}\right) \mid \mathrm{S}_{\mathrm{t}}\right] & \left.=\mathrm{E}\left[\bar{C}_{3}\left(\mathrm{~S}_{\mathrm{t}}, \mathrm{t}\right) \mathrm{R}-\bar{C}_{3}\left(\mathrm{~S}_{\mathrm{t}+1}, \mathrm{t}+1\right)\right\} \mathrm{I}\left(\mathrm{S}_{\mathrm{t}+1}-\mathrm{x}\right) \mid \mathrm{S}_{\mathrm{t}}\right] \\
& =0 .
\end{aligned}
$$

Proof of Proposition 2: It suffices to prove that

$$
\Delta_{\mathrm{t}} \equiv \mathrm{J}\left(\mathrm{x}+\bar{C}_{3}\left(\mathrm{~S}_{\mathrm{t}}, \mathrm{t}\right), \mathrm{y}, \mathrm{S}_{\mathrm{t}}, \mathrm{t}\right)-\mathrm{V}(\mathrm{x}, \mathrm{y}, \mathrm{t}) \geq 0, \mathrm{t} \leq \mathrm{T}
$$

If, indeed, equation (A.14) holds at date $t$, we consider the zero-net-cost policy of writing a call 
option for cash price of $\bar{C}_{3}\left(\mathrm{~S}_{\mathrm{t}}, \mathrm{t}\right)$ and investing the proceeds in the cash account. The increase in the investor's expected utility is $\Delta_{\mathrm{t}}$ and is positive, by equation (A.14). Therefore, the investor's reservation write price is bounded above by $\bar{C}_{3}\left(\mathrm{~S}_{\mathrm{t}}, \mathrm{t}\right)$ and the proposition follows.

The proof of equation (A.14) is by induction. Equation (A.14) holds at $t=T$ because

$$
\begin{aligned}
\Delta_{\mathrm{T}} & =\mathrm{J}\left(\mathrm{x}+\bar{C}_{3}\left(\mathrm{~S}_{\mathrm{T}}, \mathrm{T}\right), \mathrm{y}, \mathrm{S}_{\mathrm{T}}, \mathrm{T}\right)-\mathrm{V}(\mathrm{x}, \mathrm{y}, \mathrm{T}) \\
& =\mathrm{V}\left(\mathrm{x}-\left(\mathrm{S}_{\mathrm{T}}-\mathrm{K}\right)^{+}+\bar{C}_{3}\left(\mathrm{~S}_{\mathrm{T}}, \mathrm{T}\right), \mathrm{y}, \mathrm{T}\right)-\mathrm{V}(\mathrm{x}, \mathrm{y}, \mathrm{T}) \\
& =0,
\end{aligned}
$$

by the definition of $\bar{C}_{3}\left(\mathrm{~S}_{\mathrm{T}}, \mathrm{T}\right)$ in equation (5.9). Next, we assume that equation (A.14) holds for some $\mathrm{t}+1, \mathrm{t}+1 \leq \mathrm{T}$ and prove that it holds for $\mathrm{t}$ also. Let $\mathrm{v}_{\mathrm{t}}$ be the optimal investment decision at date $\mathrm{t}$ for the investor who does not trade in the derivative. Then

$$
\begin{aligned}
& \Delta_{\mathrm{t}}=\mathrm{J}\left(\mathrm{x}+\bar{C}_{3}\left(\mathrm{~S}_{\mathrm{t}}, \mathrm{t}\right), \mathrm{y}, \mathrm{S}_{\mathrm{t}}, \mathrm{t}\right)-\mathrm{V}(\mathrm{x}, \mathrm{y}, \mathrm{t}) \\
& \geq \mathrm{E}\left[\mathrm{J}\left(\left\{\mathrm{x}-\mathrm{v}_{\mathrm{t}}-\max \left[\mathrm{k}_{1} \mathrm{v}_{\mathrm{t}},-\mathrm{k}_{2} \mathrm{v}_{\mathrm{t}}\right]+\bar{C}_{3}\left(\mathrm{~S}_{\mathrm{t}}, \mathrm{t}\right)\right\} \mathrm{R},\left(\mathrm{y}+\mathrm{v}_{\mathrm{t}}\right) \mathrm{S}_{\mathrm{t}+1} / \mathrm{S}_{\mathrm{t}}, \mathrm{S}_{\mathrm{t}+1}, \mathrm{t}+1\right)\right. \\
& \left.\quad-\mathrm{V}\left(\left\{\mathrm{x}-\mathrm{v}_{\mathrm{t}}-\max \left[\mathrm{k}_{1} \mathrm{v}_{\mathrm{t}},-\mathrm{k}_{2} \mathrm{v}_{\mathrm{t}}\right]\right\} \mathrm{R},\left(\mathrm{y}+\mathrm{v}_{\mathrm{t}}\right) \mathrm{S}_{\mathrm{t}+1} / \mathrm{S}_{\mathrm{t}}, \mathrm{t}+1\right) \mid \mathrm{S}_{\mathrm{t}}\right],
\end{aligned}
$$


by the definition of the functions $\mathrm{V}$ and $\mathrm{J}$ and the fact that $\mathrm{V}_{\mathrm{t}}$ is the optimal investment decision for the V-problem but not necessarily for the J-problem,

$$
\begin{aligned}
& \geq \mathrm{E}\left[\mathrm{V}\left(\left\{\mathrm{x}-\mathrm{v}_{\mathrm{t}}-\max \left[\mathrm{k}_{1} \mathrm{v}_{\mathrm{t}},-\mathrm{k}_{2} \mathrm{v}_{\mathrm{t}}\right]+\bar{C}_{3}\left(\mathrm{~S}_{\mathrm{t}}, \mathrm{t}\right)\right\} \mathrm{R}-\bar{C}_{3}\left(\mathrm{~S}_{\mathrm{t}+1}, \mathrm{t}+1\right),\left(\mathrm{y}+\mathrm{v}_{\mathrm{t}}\right) \mathrm{S}_{\mathrm{t}+1} / \mathrm{S}_{\mathrm{t}}, \mathrm{S}_{\mathrm{t}+1}, \mathrm{t}+1\right)\right. \\
& \left.\quad-\mathrm{V}\left(\left\{\mathrm{x}-\mathrm{v}_{\mathrm{t}}-\max \left[\mathrm{k}_{1} \mathrm{v}_{\mathrm{t}},-\mathrm{k}_{2} \mathrm{v}_{\mathrm{t}}\right]\right\} \mathrm{R},\left(\mathrm{y}+\mathrm{v}_{\mathrm{t}}\right) \mathrm{S}_{\mathrm{t}+1} / \mathrm{S}_{\mathrm{t}}, \mathrm{t}+1\right) \mid \mathrm{S}_{\mathrm{t}}\right],
\end{aligned}
$$

by the assumption that equation (A.14) holds for $\mathrm{t}+1$,

$$
\begin{aligned}
\geq \mathrm{E}\left[\mathrm{V}\left(\left\{\mathrm{x}-\mathrm{v}_{\mathrm{t}}-\max \left[\mathrm{k}_{1} \mathrm{v}_{\mathrm{t}},-\mathrm{k}_{2} \mathrm{v}_{\mathrm{t}}\right]\right\} \mathrm{R},\left(\mathrm{y}+\mathrm{v}_{\mathrm{t}}\right) \mathrm{S}_{\mathrm{t}+1} / \mathrm{S}_{\mathrm{t}}+\mathrm{h}\left(\mathrm{S}_{\mathrm{t}}, \mathrm{S}_{\mathrm{t}+1}, \mathrm{t}\right), \mathrm{t}+1\right)\right. \\
\left.-\mathrm{V}\left(\left\{\mathrm{x}-\mathrm{v}_{\mathrm{t}}-\max \left[\mathrm{k}_{1} \mathrm{v}_{\mathrm{t}},-\mathrm{k}_{2} \mathrm{v}_{\mathrm{t}}\right]\right\} \mathrm{R},\left(\mathrm{y}+\mathrm{v}_{\mathrm{t}}\right) \mathrm{S}_{\mathrm{t}+1} / \mathrm{S}_{\mathrm{t}}, \mathrm{t}+1\right) \mid \mathrm{S}_{\mathrm{t}}\right],
\end{aligned}
$$

We define $\mathrm{V}_{\mathrm{y}}$ as the partial derivative of $\mathrm{V}\left(\left\{\mathrm{x}-\mathrm{v}_{\mathrm{t}}-\max \left[\mathrm{k}_{1} \mathrm{v}_{\mathrm{t}},-\mathrm{k}_{2} \mathrm{~V}_{\mathrm{t}}\right]\right\} \mathrm{R},\left(\mathrm{y}+\mathrm{v}_{\mathrm{t}}\right) \mathrm{S}_{\mathrm{t}+1} / \mathrm{S}_{\mathrm{t}}+\mathrm{h}\left(\mathrm{S}_{\mathrm{t}}, \mathrm{S}_{\mathrm{t}+1}\right.\right.$, t), $t+1$ ) with respect to its second argument. Then

$$
\Delta_{\mathrm{t}} \geq \mathrm{E}\left[\mathrm{V}_{\mathrm{y}} \mathrm{h}\left(\mathrm{S}_{\mathrm{t}}, \mathrm{S}_{\mathrm{t}+1}, \mathrm{t}\right) \mid \mathrm{S}_{\mathrm{t}}\right],
$$

since $\mathrm{V}$ is concave in its second argument,

$$
\geq V_{y}\left(\text { at } S_{t+1}=x\right) E\left[h\left(S_{t}, S_{t+1}, t\right) \mid S_{t}\right]
$$


since $\mathrm{V}_{\mathrm{y}}$ is decreasing in its second argument and $\mathrm{h}\left(\mathrm{S}_{\mathrm{t}}, \mathrm{S}_{\mathrm{t}+1}, \mathrm{t}\right)>0$, as $\mathrm{S}_{\mathrm{t}+1}>\mathrm{x}$,

$$
\geq 0
$$

since $E\left[h\left(S_{t}, S_{t+1}, t\right) \mid S_{t}\right]=0$, by Lemma 2.2 . 


\section{REFERENCES}

Avellaneda, M., Paras, A., 1994. Optimal Hedging Portfolios for Derivative Securities in the Presence of Large Transaction Costs, Applied Mathematical Finance 1.

Bensaid, B., Lesne, J-P., Pagés H., Scheinkman, J., 1992. Derivative Asset Pricing with Transaction Costs, Mathematical Finance 2, 63-86.

Black, F., Scholes, M. S., 1973. The Pricing of Options and Corporate Liabilities, Journal of Political Economy 81, 637-654.

Boyle, P. P., Vorst, T., 1992. Option Replication in Discrete Time with Transaction Costs, Journal of Finance 47, 271-293.

Brennan, M. J., Schwartz, E. S., 1979. Alternative Investment Strategies for the Issuers of Equity Linked Life Insurance Policies with an Asset Value Guarantee, Journal of Business 52, 63-93.

Constantinides, G. M., 1979. Multiperiod Consumption and Investment Behavior with Convex Transactions Costs, Management Science 25, 1127-37.

Constantinides, G. M., Zariphopoulou, T., 1999. Bounds on Prices of Contingent Claims in an 
Intertemporal Economy with Proportional Transaction Costs and General Preferences, Finance and Stochastics 3, 345-369.

Constantinides, G. M., Zariphopoulou, T., 2001. Bounds on Derivative Prices in an Intertemporal Setting with Proportional Transaction Costs and Multiple Securities, Mathematical Finance, forthcoming.

Davis, M. H. A., Clark, J. M. C., 1993. Analysis of Financial Models Including Transaction Costs, Royal Society Discussion Meeting in Mathematical Models in Finance. London, November 10-11.

Davis, M. H. A., Panas V. G., Zariphopoulou, T., 1993. European Option Pricing with Transaction Costs, SIAM Journal of Control and Optimization 31, 470-493.

Edirisinghe, C., Naik V., Uppal, R., 1993. Optimal Replication of Options with Transactions Costs and Trading Restrictions, Journal of Financial and Quantitative Analysis 28, 117138.

Figlewski, S., 1989. Options Arbitrage in Imperfect Markets, Journal of Finance 44, 1289-1311.

Grannan, E. R., Swindle, G.H., 1996. Minimizing Transaction Costs of Option Hedging Strategies, Mathematical Finance 6, 341-364. 
Hodges, S. D., Neuberger, A., 1989. Optimal Replication of Contingent Claims under Transaction Costs, Review of Futures Markets 8, 222-239.

Hoggard, T., Whalley, A. E., Wilmott, P., 1993. Hedging Option Portfolios in the Presence of Transaction Costs, Advances in Futures and Options Research.

Jackwerth, J.C., Rubinstein, M., 1996. Recovering Probability Distributions from Option Prices, Journal of Finance 51, 1611-1631.

Leland, H. E., 1985. Option Pricing and Replication with Transactions Costs, Journal of Finance 40, 1283-1301.

Levy, H., 1985. Upper and Lower Bounds of Put and Call Option Value: Stochastic Dominance Approach, Journal of Finance 40, 1197-1217.

Merton, R. C., 1990. Continuous-Time Finance (Basil Blackwell, Oxford).

Perrakis, S., 1986. Option Bounds in Discrete Time: Extensions and the Pricing of the American Put, Journal of Business 59, 119-141.

Perrakis, S., 1988. Preference-free Option Prices when the Stock Return Can Go Up, Go Down, 
or Stay the Same, Advances in Futures and Options Research 3, 209-235.

Perrakis, S., Lefoll, J., 1997. Derivative Asset Pricing with Transaction Costs: an Extension, Computational Economics 10, 359-376.

Perrakis, S., Ryan, P. J., 1984. Option Pricing Bounds in Discrete Time, Journal of Finance 39, $519-525$.

Ritchken, P. H., 1985. On Option Pricing Bounds, Journal of Finance 40, 1219-1233.

Ritchken, P.H., Kuo, S., 1988. Option Bounds with Finite Revision Opportunities, Journal of Finance 43, 301-308.

Soner, H. M., Shreve S. E., Cvitanic, J., 1995. There is No Nontrivial Hedging Portfolio for Option Pricing with Transaction Costs, The Annals of Applied Probability 5, 327-355.

Toft, K. B., 1996. On the Mean-Variance Tradeoff in Option Replication with Transaction Costs, Journal of Financial and Quantitative Analysis 31, 233-263. 
Table 1

The Reservation Write Price of a 3-Month European Call

with 1\% Transaction Cost Rate ${ }^{1 \mathrm{a}}$

(\% implied volatility in parenthesis)

\begin{tabular}{|l|l|l|l|}
\hline Strike-to-price ratio & 0.95 & 1.00 & 1.05 \\
\hline Black-Scholes price & 6.07 & 2.99 & 1.19 \\
& $(15.0)$ & $(15.0)$ & $(15.0)$ \\
\hline Proposition 1 bound, & 6.93 & 3.57 & 1.50 \\
any trading interval & $(20.3)$ & $(17.9)$ & $(16.8)$ \\
\hline Proposition 2 bound, & 6.91 & 3.57 & 1.51 \\
trading interval 3 months & $(20.1)$ & $(17.9)$ & $(16.9)$ \\
\hline Proposition 2 bound, & 6.89 & 3.55 & 1.49 \\
trading interval 1 month & $(20.0)$ & $(17.8)$ & $(16.8)$ \\
\hline Proposition 2 bound, & 6.88 & 3.55 & 1.49 \\
trading interval 1/2 month & $(20.0)$ & $(17.8)$ & $(16.8)$ \\
\hline Leland price, trading interval 1/250 years ${ }^{1 \mathrm{~b}}$ & 8.36 & 5.42 & 3.28 \\
& $(28.3)$ & $(27.2)$ & $(26.5)$ \\
\hline Leland price, trading interval 1/52 years ${ }^{1 \mathrm{c}}$ & 7.59 & 4.50 & 2.38 \\
& $(24.0)$ & $(22.8)$ & $(21.7)$ \\
\hline
\end{tabular}

1a The parameter values are $\mathrm{r}=0, \mu=0.04, \sigma=0.15, \mathrm{~S}_{0}=100, \mathrm{k}_{1}=\mathrm{k}_{2}=0.01, \mathrm{~T}=0.25$ years.

$1 \mathrm{~b}$ The corresponding Leland prices, without an adjustment for the initial hedging cost, are 7.69, 4.90, and 2.91, respectively.

${ }^{1 \mathrm{c}}$ The corresponding Leland prices, without an adjustment for the initial hedging cost, are 6.88, 3.98, and 2.05, respectively. 
Table 2

The Reservation Write Price of a 3-Month European Call with 3\% Transaction Cost Rate ${ }^{2 a}$ (implied volatility in parenthesis)

\begin{tabular}{|l|l|l|l|}
\hline Strike-to-price ratio & 0.95 & 1.00 & 1.05 \\
\hline Black-Scholes price & 6.07 & 2.99 & 1.19 \\
& $(15.0)$ & $(15.0)$ & $(15.0)$ \\
\hline Proposition 1 bound, & 7.21 & 3.72 & 1.56 \\
any trading interval & $(21.9)$ & $(18.7)$ & $(17.2)$ \\
\hline Proposition 2 bound, & 7.02 & 3.65 & 1.55 \\
trading interval 3 months & $(20.8)$ & $(18.3)$ & $(17.1)$ \\
\hline Proposition 2 bound, & 6.95 & 3.59 & 1.51 \\
trading interval 1 month & $(20.4)$ & $(18.0)$ & $(16.9)$ \\
\hline Proposition 2 bound, & 6.92 & 3.58 & 1.51 \\
trading interval 1/2 month & $(20.2)$ & $(18.0)$ & $(16.9)$ \\
\hline Leland price, trading interval 1/250 years ${ }^{2 b}$ & 11.86 & 8.97 & 6.58 \\
& $(47.1)$ & $(45.1)$ & $(43.4)$ \\
\hline Leland price, trading interval 1/52 years ${ }^{2 \mathrm{c}}$ & 10.18 & 7.02 & 4.59 \\
& $(38.2)$ & $(35.2)$ & $(33.3)$ \\
\hline
\end{tabular}

${ }^{2 \mathrm{a}}$ The parameter values are $\mathrm{r}=0, \mu=0.04, \sigma=0.15, \mathrm{~S}_{0}=100, \mathrm{k}_{1}=\mathrm{k}_{2}=0.03, \mathrm{~T}=0.25$ years.

${ }^{2 b}$ The corresponding Leland prices, without an adjustment for the initial hedging cost, are 9.94, 7.35, and 5.29, respectively.

${ }^{2 c}$ The corresponding Leland prices, without an adjustment for the initial hedging cost, are 8.17, 5.43, and 3.42, respectively. 
Table 3

The Reservation Purchase Price of a 3-Month European Put ${ }^{3 a}$

(\% implied volatility in parenthesis)

\begin{tabular}{|l|l|l|l|}
\hline Strike-to-price ratio & 0.95 & 1.00 & 1.05 \\
\hline Black-Scholes price & 1.07 & 2.99 & 6.19 \\
& $(15.0)$ & $(15.0)$ & $(15.0)$ \\
\hline Proposition 6 bound, 1\% transaction cost & 0.83 & 2.46 & 5.32 \\
rate, any trading interval & $(13.4)$ & $(12.3)$ & $(8.9)$ \\
\hline Proposition 6 bound, 3\% transaction cost & 0.80 & 2.35 & 5.11 \\
rate, any trading interval & $(13.2)$ & $(11.8)$ & $(6.7)$ \\
\hline
\end{tabular}

3a The parameter values are $\mathrm{r}=0, \mu=0.04, \sigma=0.15, \mathrm{~S}_{0}=100, \mathrm{~T}=0.25$ years. 